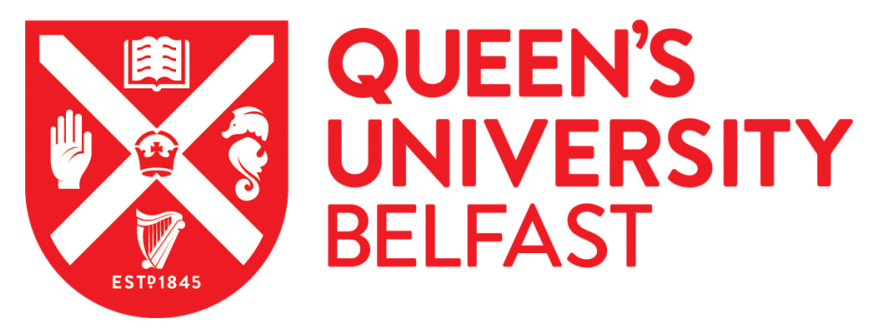

\title{
Designing effective homogeneous catalysis for glycerol valorisation: selective synthesis of a value-added aldehyde from 1,3-propanediol via hydrogen transfer catalysed by a highly recyclable, fluorinated Cp*Ir(NHC) catalyst
}

Ma, Y., Wang, Y., Morgan, P. J., Jackson, R. E., Liu, X., Saunders, G., Lorenzini, F., \& Marr, A. C. (2018). Designing effective homogeneous catalysis for glycerol valorisation: selective synthesis of a value-added aldehyde from 1,3-propanediol via hydrogen transfer catalysed by a highly recyclable, fluorinated $\mathrm{Cp} * \mathrm{r}(\mathrm{NHC})$ catalyst. Catalysis Today, 307, 248-259. https://doi.org/10.1016/j.cattod.2017.09.036

\section{Published in:}

Catalysis Today

Document Version:

Peer reviewed version

Queen's University Belfast - Research Portal:

Link to publication record in Queen's University Belfast Research Portal

\section{Publisher rights}

Copyright 2017 Elsevier.

This manuscript is distributed under a Creative Commons Attribution-NonCommercial-NoDerivs License

(https://creativecommons.org/licenses/by-nc-nd/4.0/), which permits distribution and reproduction for non-commercial purposes, provided the author and source are cited.

\section{General rights}

Copyright for the publications made accessible via the Queen's University Belfast Research Portal is retained by the author(s) and / or other copyright owners and it is a condition of accessing these publications that users recognise and abide by the legal requirements associated with these rights.

\section{Take down policy}

The Research Portal is Queen's institutional repository that provides access to Queen's research output. Every effort has been made to ensure that content in the Research Portal does not infringe any person's rights, or applicable UK laws. If you discover content in the Research Portal that you believe breaches copyright or violates any law, please contact openaccess@qub.ac.uk. 
Designing effective homogeneous catalysis for glycerol valorisation: selective synthesis of a value-added aldehyde from 1,3-propanediol via hydrogen transfer catalysed by a highly recyclable, fluorinated $\mathrm{Cp} * \operatorname{Ir}(\mathrm{NHC})$ catalyst.

Yueyuan Ma, ${ }^{a}$ Yue-Ming Wang, ${ }^{\text {a,b }}$ Patrick J. Morgan, ${ }^{a}$ Rachael E. Jackson, ${ }^{a}$ Xiao-han Liu, a,b Graham C. Saunders, ${ }^{c}$ Fabio Lorenzini, ${ }^{* a}$ and Andrew C. Marr.*a,b

${ }^{a}$ School of Chemistry and Chemical Engineering, Queen's University of Belfast, UK.

${ }^{b}$ Queen's University Ionic Liquids Laboratories (QUILL), UK.

${ }^{c}$ School of Science, The University of Waikato, Hamilton 3240, New Zealand.

*Fabio.Lorenzini@qub.ac.uk

*a.marr@qub.ac.uk

\begin{abstract}
.
Hydrogen transfer initiated dehydration (HTID) of 1,3-propanediol (1,3-PDO), in ionic liquids, catalysed by a fluorinated $\mathrm{Cp}^{*} \mathrm{IrCl}_{2}(\mathrm{NHC})\left(\mathrm{Cp}^{*}=\right.$ pentamethylcyclopentadienyl; $\mathrm{NHC}=$ carbene ligand) complex, allows selective production of propionaldehyde in high yields, under air. Isolation of the product is facilitated by the use of an ionic liquid as the solvent, enabling the reaction to be performed under reduced pressure. The Ir(III) catalyst in ionic liquid was proven to be highly recyclable. Removal of $\mathrm{H}$ and $\mathrm{F}$ atoms bound to the ortho-C atoms of the benzyl arm of the carbene ligand inhibits the catalytic activity of complexes $\mathrm{Cp}^{*} \mathrm{IrCl}_{2}(\mathrm{NHC})$, suggesting a crucial role played by the ortho-C-X grouping in HTID. The reaction of 1,3-PDO solutions in ionic liquid mimics that of the product of extraction of aqueous glycerol fermentation broths: the successful synthesis and isolation of a value-added chemical proves that valorisation of glycerol waste can be achieved. The combination of $\mathrm{Cp}^{*} \mathrm{IrX}_{2}$ (NHC) - catalysed HTID of 1,3-PDO in ionic liquids with biocatalysis has then, ultimately, the potential to allow the transformation of waste glycerol into valuable chemicals that can be simply isolated.
\end{abstract}

Keywords: Iridium, catalysis, ionic liquids, glycerol, 1,3-propanediol, biomass. 


\section{Introduction.}

For decades petrochemicals have been conveniently and economically generated concurrently with liquid fuel processing on a massive scale. As the human population increases, and the fossil fuel era dwindles, energy and chemicals technologies have to diversify. Many of the newer sources of useful energy cannot be coupled to chemicals production and new sources of chemicals are becoming important. Prior to the petrochemical era it was common to generate important bulk chemicals from biomass and this is again becoming profitable. Biomass is unique amongst the more renewable technologies as it can be employed to generate fuel and chemicals simultaneously in a biorefinery, this provides economics similar to petroleum and petrochemicals. Furthermore biomass is ubiquitous, as animals must eat. Ideally liquids fuels and chemicals will be derived from the waste from agriculture thus supporting, rather than competing with, food production. For example used vegetable oil can be transformed into biodiesel and the side product, glycerol, can be converted into chemicals.

In the biomass Renaissance one of the first platform chemicals to emerge was 1,3propanediol. 1,3-propanediol (1,3-PDO) is a renewable platform chemical ${ }^{1}$ that can be readily prepared by large scale whole cell biocatalysis. ${ }^{2}$ Bio-derived 1,3-propanediol is currently produced by the bacterial fermentation of sugars, for example sugars derived from corn., 1,3-PDO can be obtained at a competitive cost and is commercially available from DuPont ${ }^{\mathrm{TM}}$ (marketed as Bio-PDO $\left.{ }^{\mathrm{TM}}\right){ }^{3}$ The whole cell biocatalytic preparation of 1,3-PDO introduced by DuPont ${ }^{\mathrm{TM}}$ and Tate \& Lyle has considerable environment benefits compared to the petrochemical route. ${ }^{4}$ DuPont ${ }^{\mathrm{TM}}$ estimate a reduction in energy consumption of $40 \%$ and a reduction of greenhouse gas emissions of more than $40 \%$. Further improvements could be adopted by converting the feedstock to the by-product of biodiesel production, glycerol. 1,3PDO is a major product of glycerol fermentation by Clostridium, ${ }^{5}$ Klebsiella, Citrobacter, ${ }^{6}$

1 U.S. Department of Energy (2004) Top Value Added Chemicals from Biomass (Vol. 1) (Ed's T. Werpy and G. Petersen), Pacific Northwest National Laboratory (PNNL), National Renewable Energy Laboratory (NREL),Office of Biomass Program (EERE). http://www.eere.energy.gov/.

2 T. Banner, A. Fosmer, H. Jessen, E. Marasco, B. Rush, J. Veldhouse, M. De Souza, "Biocatalysis for Green Chemistry and Chemical Process Development," ed's J. Tao and R. Kazlauskas, Wiley, New Jersey (2011) 429.

3 C.E. Nakamura, A.A. Gatenby, A. Kuang-Hua Hsu, R.D. La Reau, S.L. Haynie, M. Diaz-Torres, D.E. Trimbur, G.M. Whited, V. Nagarajan, M.S. Payne, S.K. Picataggio, R.V. Nair, US6013494, Jan 112000 , "Method for the production of 1,3-propanediol by recombinant microorganisms", A, E. I. Du Pont De Nemours And Company, Genencor International.

4 C.S. Lee, M.K. Aroua, W.M.A.W. Daud, P. Cognet, Y. Pérès-Lucchese, P.-L. Fabre, O. Reynes, L. Latapie, Renew. Sust. Energ. Rev. 42 (2015) 963.

5 P. Kubiak, K. Leja, K. Myszka, E. Celinska, M. Spychała, D. Szymanowska-Powałowska, K. Czaczyk, W. Grajek, Process Biochem. 47 (2012), 1308.

6 R.K. Saxena, P. Anand, S. Saran, J. Isar, Biotechnol. Adv. 27 (2009) 895. 
Lactobacillus, $^{7}$ and genetically modified microorganisms. ${ }^{8}$ Clostridium butyricum has been shown to convert crude glycerol from biodiesel production to $1,3-\mathrm{PDO},{ }^{9}$ further studies focused on direct crude glycerol fermentations have recently been reported. ${ }^{10}$

The Bio-1,3-PDO generated by DuPont ${ }^{\mathrm{TM}}$ is predominantly used for polymer synthesis. The importance of this biorenewable platform chemical has inspired us to investigate catalytic transformation of 1,3-PDO into other useful chemicals. We have previously shown that the biocatalytic conversion of glycerol to 1,3-PDO can be coupled to hydrogen transfer catalysed amination by using an ionic liquid as the phase for chemocatalysis in order to prepare secondary amines. ${ }^{9}$ Combining bio- and chemo-catalysis in this way removes the need for intermediate separation as 1,3-PDO can be extracted in situ by the solvent for chemocatalysis. ${ }^{11}$ Ionic liquids were subsequently proven to be excellent solvents for the amination reaction enabling the fine-tuning of the product obtained. ${ }^{12}$ More unexpected was the observation that dehydration of the diol occurred simultaneously with amination, this observation was quite unique in the reactivity of aliphatic alcohols and was most likely due to the 1,3-diol configuration. ${ }^{13}$ Further investigations revealed that, in the absence of amine dehydration could be affected to yield propionaldehyde as the major product. ${ }^{14}$ This occurs due to dehydrogenation of 1,3-PDO, which yields an aldol that rapidly dehydrates to acrolein and is then hydrogenated to propionaldehyde. This is a Hydrogen Transfer Initiated Dehydration (HTID) reaction. The reaction was catalysed by a $\mathrm{Cp}^{*} \operatorname{IrCl}_{2}(\mathrm{NHC})\left(\mathrm{Cp}^{*}=\right.$ pentamethylcyclopentadienyl; NHC = carbene ligand) catalyst. Cp* $\operatorname{Ir}(\mathrm{III})$ complexes have excellent hydrogen transfer and dehydrogenation activity coupled to high air and water stability and have been demonstrated for amination, ${ }^{15}$ Oppenauer-type oxidation, ${ }^{16}$ dehydrogenation, ${ }^{17}$ the Guerbet reaction, ${ }^{18}$ and dynamic kinetic resolution (DKR). ${ }^{19}$

7 M.A. Ricci, A. Russo, I. Pisano, L. Palmieri, M. de Angelis, G. Agrimi, J. Microbiol. Biotechnol. 25 (2015) 893.

8 C.E. Nakamura, G.M. Whited, Curr. Opin. Biotech. 14 (2003) 454.

9 S.F. Liu, M. Rebros, G. Stephens, A.C. Marr, Chem. Commun. (2009) 2308.

10 (a) E. Wilkens, A.K. Ringel, D. Hortig, T. Willke, K.-D. Vorlop, Appl. Microbiol. Biotechnol. 93 (2012)

1057; (b) D. Dietz, A.-P. Zeng, Bioprocess Biosyst. Eng. 37 (2014) 225; (c) R. Dobson, V. Gray, K. Rumbold,

J. Ind. Microbiol. Biotechnol. 39 (2012) 217.

11 A.C. Marr, S.F. Liu, Trends Biotech. 29 (2011) 199.

12 S.D. Lacroix, A. Pennycook, S. Liu, T.T. Eisenhart, A.C. Marr, Catal. Sci. Technol. 2 (2012) 288.

13 A.C. Marr, Catal. Sci. Technol. 2 (2012) 279.

14 Y.-M. Wang, F. Lorenzini, M. Rebros, G.C. Saunders, A.C. Marr, Green Chem. 18 (2016) 1751.

15 (a) M. Pera-Titus, F. Shi, ChemSusChem 7 (2014) 720; (b) G. Guillena, D.J. Ramón, M. Yus, Chem. Rev.

110 (2010) 1611; (c) S. Bähn, S. Imm, L. Neubert, M. Zhang, H. Neumann, M. Beller, ChemCatChem 3 (2011) 1853.

16 F. Hanasaka, K. Fujita, R. Yamaguchi, Organometallics 23 (2004) 1490.

17 (a) G.E. Dobereiner, R.H. Crabtree, Chem. Rev. 110 (2010) 681; (b) C. Gunanathan, D. Milstein, Science 341 (2013) 1229712; (c) J. Wu, D. Talwar, S. Johnston, M. Yan, J-L. Xiao, Angew. Chem. Int. Ed. 52 (2013) 6983. 
An example of the use of IrCp* complexes as efficient dehydrogenation catalysts was recently reported by J. Xiao and co-workers. A cyclometalated $\left[\mathrm{Cp}^{*} \mathrm{Ir}^{\mathrm{III}}\right] /$ imino complex (Imine $=4$-methoxy- $N$-[1-(3-methoxy-phenyl)ethylidene $]$ aniline $)$ was found to be a versatile catalyst for the rare, homogeneous, catalytic dehydrogenation of various benzo-fused $\mathrm{N}$ heterocycles such as tetrahydroquinolines, tetrahydroisoquinolines, 3,4-dihydroisoquinolines, tetrahydro- $\beta$-carbolines, indolines, and tetrahydroquinoxalines. High yields of quinolines, isoquinolines, $\beta$-carbolines, indoles, and quinoxalines, respectively, were obtained using the cyclometalated $\left[\mathrm{Cp}^{*} \mathrm{Ir}^{\mathrm{III}}\right] /$ imino complex, in concentration $0.1-1 \mathrm{~mol} \%$, in refluxing 2,2,2trifluoroethanol. ${ }^{20}$ Furthermore, in the case of isoquinolines and 3,4-dihydroisoquinolines, the $\mathrm{Cp}^{*} \mathrm{Ir}^{\mathrm{III}}$ complex was also found to be an efficient catalyst for the reverse process, that is hydrogenation to tetrahydroisoquinolines: ultimately, J. Xiao and co-workers designed an interchangeable catalytic network that links the three forms of isoquinoline by hydrogenation and dehydrogenation equilibria, using the $\mathrm{Cp}^{*} \operatorname{Ir}^{\mathrm{III}}$ catalyst in 2,2,2-trifluoroethanol at the specific temperatures and catalyst loadings allowing the six different transformations to occur as required. The ability of the $\mathrm{Cp}^{*} \mathrm{Ir}^{\mathrm{III}}$ complex to catalyse the dehydrogenation of 3,4dihydroisoquinolines was applied in a three-step total synthesis of papaverine, an opium alkaloid antispasmodic drug, clinically used for vasospasm treatment, while the Cp*IrIIcatalysed dehydrogenation of tetrahydro- $\beta$-carbolines found application in a two-step total synthesis of harmine, a $\beta$-carboline alkaloid with cytotoxic activities against a series of tumor cell lines.

In the IrCp*-catalysed Guerbet reaction, a sequence of dehydrogenation, self aldol condensation, dehydration, and hydrogenation allows the transformation of primary aliphatic alcohols to dimeric alcohols via formation of aldehydes. In 2006 Y. Ishii and co-workers reported an efficient $\mathrm{IrCp}^{*}$-catalyzed Guerbet reaction of several primary linear, and branched, alcohols to $\beta$-alkylated primary alcohols under mild conditions: up to almost quantitative yields of the latter were obtained in $p$-xylene, at $120^{\circ} \mathrm{C}$, in the presence of $\mathrm{KOH}$ or $t-\mathrm{BuOH}$, and hydrogen acceptors such as 1,7 -octadiene, cyclooctene and 1 -octene. ${ }^{18 \mathrm{c}}$

18 (a) M. Guerbet, C. R. Acad. Sci. 128 (1899) 1002; (b) M. Guerbet, C. R. Acad. Sci. 149 (1909) 129; (c) T. Matsu-ura, S. Sakaguchi, Y. Obora, Y. Ishii, J. Org. Chem. 71 (2006) 8306.

19 (a) A.C. Marr, C.L. Pollock, G.C. Saunders, Organometallics 26 (2007) 3283; (b) R. Corberán, E. Peris, Organometallics 27 (2008) 1954; (c) T. Jerphagnon, R. Haak, F. Berthiol, A.J.A. Gayet, V. Ritleng, A. Holuigue, N. Pannetier, M. Pfeffer, A. Voelklin, L. Lefort, G. Verzijl, C. Tarabiono, D.B. Janssen, A.J. Minnaard, B.L. Feringa, J.G. de Vries, Top. Catal. 53 (2010) 1002; (d) C.L. Pollock, K.J. Fox, S.D. Lacroix, J. McDonagh, P.C. Marr, A.M. Nethercott, A. Pennycook, S. Qian, L. Robinson, G.C. Saunders, A.C. Marr, Dalton Trans. 41 (2012) 13423; (e) J.G. de Vries, Top. Catal. 57 (2014) 1306.

20 J. Wu, D. Talwar, S. Johnston, M. Yan, J. Xiao, Angew. Chem. Int. Ed. 52 (2013) 6983. 
The production of propionaldehyde directly from 1,3-PDO, using a heterogeneous copper catalyst at high temperature, was reported by S. Sato et al. in 2008. The vapour-phase dehydration of 1,3-PDO over $\mathrm{Cu}-\mathrm{Al}_{2} \mathrm{O}_{3}$ at $250{ }^{\circ} \mathrm{C}$ afforded propionaldehyde with $66 \%$ selectivity. ${ }^{21}$ The dehydration of the substrate proceeded at $100 \%$ conversion to yield propionaldehyde together with propanoic acid, 2-ethyl-1,3-dioxane, and acetaldehyde as byproducts. The major by-product, propanoic acid, formed with $18 \%$ selectivity, is likely to result from the oxidation of propionaldehyde with water as oxidant. S. Sato and co-workers suggested that formation of propionaldehyde from 1,3-PDO occurs either via a dehydrogenation-dehydration-hydrogenation or a dehydration-dehydrogenationhydrogenation sequence. In the former route, the substrate is first dehydrogenated to form 3hydroxypropanal; dehydration of the latter yields 2-propenal, which is finally hydrogenated to propionaldehyde. Alternatively, initial dehydration involving one of the hydroxy groups of 1,3-PDO leads to 2-propen-1-ol, which is then converted into propionaldehyde via dehydrogenation-hydrogenation: 2-propen-1-ol is first dehydrogenated to 2-propenal, which is then hydrogenated to propionaldehyde. Comparison with 1,3-butandiol (1,3-BDO) dehydration reactions suggests dehydrogenation-dehydration-hydrogenation to be the most likely reaction pathway. S. Sato and co-workers proposed this sequence for the copper catalyzed dehydration of 1,3-BDO to butanone: the diol is first dehydrogenated to 4-hydroxy2-butanone; dehydration of the latter, leading to methyl vinyl ketone, followed by hydrogenation, affords butanone. ${ }^{22}$

The C4 diol 1,3-BDO has been investigated as a model molecule for the catalytic transformation of polyols, including 1,3-diols such as 1,3-PDO, to carbonylic compounds: the understanding of its metal catalysed dehydration reactivity towards carbonylic compounds offers meaningful insights for the comprehension of the hydrogen transfer initiated dehydration of 1,3-PDO towards aldehydes hereby discussed.

1,3-BDO can undergo dehydration, dehydrogenation, or tandem dehydrogenationdehydration-hydrogenation reactions, also followed by C-C bond cleavage reactions, to yield a range of valuable products. The initial selective dehydrogenation of either the primary or the secondary hydroxy group of 1,3-BDO would generate aldol compounds, namely hydroxyaldehyde, 3-hydroxybutanal, or hydroxyketones, 4-hydroxy-2-butanone, respectively. The following dehydration-hydrogenation will deliver further valuable chemicals, namely, in the case of 4-hydroxy-2-butanone, the $\alpha, \beta$-unsaturated methyl vinyl ketone and the saturated methyl ethyl ketone. Otherwise, a different network of chemicals would be produced if the 
initial step is, instead, dehydration of 1,3-BDO: after formation of the unsaturated alcohols 3buten-2-ol or 2-buten-1-ol or 3-buten-1-ol, further hydrogenation or dehydration reactions would deliver saturated alcohols, namely 1- or 2- butanol, or olefins, namely butadiene. Direct dehydration of 1,3-BDO to methyl ethyl ketone should also be considered. A clear picture of 1,3-BDO dehydrogenation / dehydration / hydrogenation product distribution has been reported recently by Di Cosimo and co-workers studying the gas-phase reaction of 1,3$\mathrm{BDO}$ in the presence of bifunctional metal/acid-base $Z \mathrm{CuMgAl}$ catalysts $(\mathrm{Z}=0.3-61.2 \mathrm{wt}$. $\% \mathrm{Cu}, \mathrm{Mg} / \mathrm{Al}=1.5$ molar ratio), obtained with $\mathrm{Cu}-\mathrm{Mg}-\mathrm{Al}$ mixed oxides, ${ }^{23}$ or silica supported copper catalysts $\mathrm{ZCuSiO}_{2}(\mathrm{Z}=1-25$ wt. \% Cu$){ }^{24}$ Dehydrogenation of the 1,3BDO secondary hydroxy group, prevailing over that of the primary one, followed by dehydration and hydrogenation, leads to the $\beta$-hydroxy ketone 4-hydroxy-2-butanone, the $\alpha, \beta$-unsaturated ketone methyl vinyl ketone and the saturated ketone methyl ethyl ketone, as the major products, obtained in different relative amounts depending on the reaction conditions.

3-hydroxybutanal, the hydroxyaldehyde generated by the initial 1,3-BDO dehydrogenation occurring at the primary, instead of secondary, hydroxy group was observed only in minor concentrations at any reaction conditions using both the $\mathrm{ZCuSiO}_{2}$ and ZCuMgAl catalysts; instead 4-hydroxy-2-butanone was always one of the main reaction products. That does not, however, rule out the occurrence of dehydrogenation at the primary hydroxy group: while it is known that secondary alcohols are better hydrogen donors than primary alcohols, indicating that the main 1,3-BDO dehydrogenation route involves the secondary hydroxy group, it should be considered that formation of 3-hydroxybutanal in low concentration could be due to $\mathrm{C}-\mathrm{C}$ bond cleavage reactions, such as retro-aldol reactions, yielding minor compounds, namely the detected ethanol and acetaldehyde; while the dehydration-hydrogenation pathway predominates over the $\mathrm{C}-\mathrm{C}$ bond breaking route for transformation of 4-hydroxy-2-butanone, the dehydration-hydrogenation products formed from 3-hydroxybutanal were observed in negligible amounts compared to the decomposition products ethanol and acetaldehyde.

Dehydrogenation at the primary hydroxy group of 1,3-BDO to aldehyde has recently been studied by M. Tamura, K. Tomishige and co-workers when investigating the production of butanone from $\mathrm{C} 4$ diols in the presence of $\mathrm{Rh}-\mathrm{MoO}_{x} / \mathrm{SiO}_{2}$ catalyst via an intramolecular borrowing hydrogen methodology combining dehydrogenation and hydrogenolysis. ${ }^{25}$ 
Dehydrogenation at the primary hydroxy group was reported as less favourable than that at the secondary hydroxy group, which yields ketones. Dehydration activity and selectivity towards butanone lowered when moving from 2,4- to 1,3-BDO: adsorbtion of the primary hydroxy groups of the latter on the $\mathrm{MoO}_{x}$ species, where dehydrogenation of hydroxy groups generally occurs, is more favoured than that of secondary hydroxy groups; therefore, aldehydes, instead of ketones, should be produced in the first instance. However, production of $\mathrm{CO}_{2}$ and alkenes prove that the aldehydic group is indeed formed, but undergoes rhodium catalysed decarbonylation or decarboxylation, and / or retro-aldol condensation. As a consequence, dehydrogenation of the secondary $\mathrm{OH}$ group still allows formation of 2butanone, but at lower activity and selectivity.

The evidence reported by Di Cosimo and co-workers, and M. Tamura, K. Tomishige and co-workers, on the reactivity of primary hydroxy groups of 1,3-BDO towards aldehydes, along with the absence of any competing secondary hydroxy group in 1,3-PDO, support the proposed occurrence of the 1,3-PDO dehydrogenation-dehydration-hydrogenation sequence in the herein reported HTID of 1,3-PDO, which contains only primary hydroxy groups, to deliver the target propionaldehdye.

The success of the methyl, benzyl NHC ligand in the $\mathrm{Cp}^{*} \mathrm{IrCl}_{2}(\mathrm{NHC})$ catalytic system in HTID $^{14}$ inspired us to look at the effects of altering the ring substituents on the benzyl group. The efficient, selective production of propionaldehyde via HTID of 1,3-PDO, in ionic liquids, in the presence of a recyclable, fluorinated $\mathrm{Cp}^{*} \mathrm{IrCl}_{2}(\mathrm{NHC})$ catalyst precursor, is hereby presented.

\section{Experimental.}

1-Methylimidazole ( $\geq 99 \% \mathrm{w}$, Sigma-Aldrich), 2,4,6-trifluorobenzyl bromide (97 \% w, Fluorochem), 2,6-dimethylbenzyl bromide (97\% $w$, Aldrich), 1,3-propanediol (98\% $\%$, Aldrich), $\mathrm{K}_{2} \mathrm{CO}_{3}\left(99.5 \%\right.$ w, BDH), $\mathrm{KOH}$ (85 \% w, Riedel-de Haen), $\mathrm{CsCO}_{3}(99.995 \%$ w, Sigma-Aldrich), propionaldehyde (97 \% w, Aldrich), 2-methyl-2-pentenal (97\% w, Aldrich), 2-methyl-pentanal (> $95.0 \% w$, TCI), propanol (97\% $w$, Sigma-Aldrich), methanol ( $\geq 99.9$ $\% w$, CHROMASOLV, for HPLC, Sigma-Aldrich), dichloromethane ( $\geq 99 \% w$, for GC, Sigma-Aldrich), diethyl ether ( $\geq 99.5 \% w$, for GC, Sigma-Aldrich), ethyl acetate $(\geq 99.8 \%$ $w$, Lab-scan), pentane ( $\geq 99.9 \% w$, CHROMASOLV, for HPLC, Sigma-Aldrich), chloroform ( $\geq 99.8 \% \mathrm{w}$, for GC, Sigma-Aldrich), $\mathrm{CDCl}_{3}$ (99.8\% w, Aldrich), decalite (speed plus, diatomaceous filter-aid, Acros Organics), were used as received. 1-ethyl-2,3-dimethyl- 
imidazolium- $N, N$-bistriflimide $\left(\right.$ EmmimNTf $\left._{2}\right),{ }^{26}$ and methyl-tri- $n$-octyl-ammonium- $N, N$ bistriflimide $\left(\mathrm{N}_{1,8,8,8} \mathrm{NTf}_{2}\right)^{27}$ were synthesized according to literature procedures. ${ }^{1} \mathrm{H} \mathrm{NMR}$ spectra were run on $300 \mathrm{MHz}$ and $400 \mathrm{MHz}$ Bruker spectrophotometers. The chemical shifts are reported in ppm. Signal multiplicities are reported as singlet (s), doublet (d), triplet (t), and multiplet $(\mathrm{m})(\mathrm{br}=$ broad$)$. GC/MS spectroscopic data were collected on a MassHunter Workstation Software - Qualitative Analysis - Version B.06.00 - Build 6.0.663.10 - Service Pack 1 - (C) Agilent Technologies, Inc. 2012. GC/MS column: Agilent Technologies, Inc.; 19091S-433UI; HP-5MS UI; $30 \mathrm{~m} \mathrm{X} 0.250 \mathrm{~mm}$; 0.25 Micron; -60 to 325/350C; SN: USE137316H. GC/MS spectroscopic data were processed on MassHunter Data Analysis MassHunter GC/MS Acquisition B.07.01.1805 - 12-Mar-2014 - (C) 1989-2014 Agilent Technologies.

\section{Synthesis of 3-methyl-1-(2,4,6-trifluorobenzyl)-imidazolium bromide (BzMIm-3F).}

1-methylimidazole $(0.685 \mathrm{~g}, 8.3 \mathrm{mmol})$ was added to a dichloromethane $(30.0 \mathrm{~mL})$ solution of 2,4,6-trifluorobenzyl bromide $(1.877 \mathrm{~g}, 8.3 \mathrm{mmol})$. The resulting, colourless solution was stirred for 48 hours. Solvent removal led to a colourless crystalline powder of BzMIm-3F that was dried overnight (2.500 g; yield $98 \%$ ). BzMIm-3F was recrystallised by diffusing diethyl ether (ca. $4.5 \mathrm{~mL})$, or ethyl acetate (ca. $4.5 \mathrm{~mL})$, or pentane (ca. $4.5 \mathrm{~mL})$ into a chloroform (ca. $0.5 \mathrm{~mL}$ ) solution of BzMIm-3F (0.5 g, $1.7 \mathrm{mmol}$; or $0.25 \mathrm{~g}, 0.9 \mathrm{mmol}$; or $0.1 \mathrm{~g}, 0.4 \mathrm{mmol}) .{ }^{1} \mathrm{H} \mathrm{NMR}\left(\mathrm{CD}_{3} \mathrm{OD}, 400 \mathrm{MHz}\right): \delta_{\mathrm{H}} 7.68\left(\mathrm{~d}, J_{\mathrm{HH}}=1.9 \mathrm{~Hz}, 1 \mathrm{H}\right.$, $\mathrm{NCH}=\mathrm{CHN}), 7.66\left(\mathrm{~d}, J_{\mathrm{HH}}=2.0 \mathrm{~Hz}, 1 \mathrm{H}, \mathrm{NCH}=\mathrm{CHN}\right), 7.11(\mathrm{dt}, J=7.9 \mathrm{~Hz}, J=3.2 \mathrm{~Hz}, 2 \mathrm{H}$, $\left.\mathrm{C}_{6} \mathrm{H}_{2} \mathrm{~F}_{3}\right), 5.58\left(\mathrm{~s}, 2 \mathrm{H}, \mathrm{CH}_{2}\right), 3.98\left(\mathrm{~s}, 3 \mathrm{H}, \mathrm{CH}_{3}\right) .{ }^{1} \mathrm{H} \mathrm{NMR}\left(\mathrm{CDCl}_{3}, 400 \mathrm{MHz}\right): \delta_{\mathrm{H}} 10.52(\mathrm{~s}, 1$ $\mathrm{H}, \mathrm{NCHN}$ ), 7.60 (br s, $1 \mathrm{H}, \mathrm{NCH}=\mathrm{CHN}$ ), 7.23 (br s, $1 \mathrm{H}, \mathrm{NCH}=\mathrm{CHN}), 6.78$ (m, $2 \mathrm{H}$, $\left.\mathrm{C}_{6} \mathrm{H}_{2} \mathrm{~F}_{3}\right), 5.65\left(\mathrm{~s}, 2 \mathrm{H}, \mathrm{CH}_{2}\right), 4.15\left(\mathrm{~s}, 3 \mathrm{H}, \mathrm{CH}_{3}\right) .{ }^{13} \mathrm{C}\left\{{ }^{1} \mathrm{H}\right\} \mathrm{NMR}\left(\mathrm{CD}_{3} \mathrm{OD}, 300 \mathrm{MHz}\right): \delta_{\mathrm{C}}$ $166.89, \quad 164.69,164.54,162.19, \quad 162.04,125.66\left(C_{6} \mathrm{H}_{2} \mathrm{~F}_{3}\right), 123.86,108.19,102.42$ $(\mathrm{CHNCH}=\mathrm{CHN}$ and $\mathrm{CHNCH}=\mathrm{CHN}), 41.67\left(\mathrm{CH}_{2}\right), 36.91\left(\mathrm{CH}_{3}\right) .{ }^{19} \mathrm{~F}\left\{{ }^{1} \mathrm{H}\right\} \mathrm{NMR}\left(\mathrm{CD}_{3} \mathrm{OD}\right.$, $400 \mathrm{MHz}): \delta_{\mathrm{F}}-105.69\left(\mathrm{t}, J_{\mathrm{FF}}=7.5 \mathrm{~Hz}, 1 \mathrm{~F}\right.$, para-F), $-112.90\left(\mathrm{~d}, J_{\mathrm{FF}}=7.5 \mathrm{~Hz}, 2 \mathrm{~F}\right.$, ortho-F). Anal. calcd. for $\mathrm{C}_{11} \mathrm{H}_{10} \mathrm{BrF}_{3} \mathrm{~N}_{2}$ : C, 43.02; H, 3.28; N, 9.12. Found: C, 42.74; H, 3.42; N, 8.78. HRMS: Clcd. $\mathrm{M}^{+} / \mathrm{Z}=227.08\left(\left[\mathrm{M}^{+}\right]\right)$. Found: $\mathrm{M}^{+} / \mathrm{Z}=227.0696\left(\left[\mathrm{M}^{+}\right]\right)$.

26 J. Wei, T. Ma, X. Ma, W. Guan, Q. Liu, J. Yang, RSC Adv. 4 (2014) 30725.

27 J.M. Fraile, J.I. García, C.I. Herrerías, J.A. Mayoral, D. Carrié, M. Vaultier, Tetrahedron: Asymmetry 12 (2001) 1891. 
Synthesis of $\quad \eta^{5}$-pentamethylcyclopentadienyl-iridium(3-methyl-1-(2,4,6trifluorobenzyl)-imidazolin-2-ylidene)-dichloride (1-3F).

$\mathrm{Ag}_{2} \mathrm{O}(0.075 \mathrm{~g}, 0.3 \mathrm{mmol})$ was added, in the absence of light, to a dichloromethane (30.0 mL) solution of BzMIm-3F (0.124 g, $0.4 \mathrm{mmol})$. The resulting mixture was stirred at room temperature for 1.5 hours. [Cp* $\left.\mathrm{IrCl}_{2}\right]_{2}(0.167 \mathrm{~g}, 0.2 \mathrm{mmol})$ was then added and the resulting mixture was stirred for 4 hours. The solution was then filtered through celite. Solvent removal led to the isolation of an orange crystalline powder of 1-3F. Recrystallisation from $\mathrm{CH}_{2} \mathrm{Cl}_{2}$ and pentane led to the isolation of yellow crystals of 1-3F (0.229 g; yield $87 \%)$. ${ }^{1} \mathrm{H} \mathrm{NMR}\left(\mathrm{CDCl}_{3}, 400 \mathrm{MHz}\right): \delta_{\mathrm{H}} 6.87\left(\mathrm{~d}, J_{\mathrm{HH}}=2.0 \mathrm{~Hz}, 1 \mathrm{H}\right.$, $\mathrm{NCH}=\mathrm{CHN}), 6.76\left(\mathrm{tm}, J=8.0 \mathrm{~Hz}, 2 \mathrm{H}, \mathrm{C}_{6} \mathrm{H}_{2} \mathrm{~F}_{3}\right), 6.48\left(\mathrm{~d}, J_{\mathrm{HH}}=2.0 \mathrm{~Hz}, 1 \mathrm{H}, \mathrm{NCH}=\mathrm{CHN}\right)$, $5.96\left(\mathrm{~d}, J_{\mathrm{HH}}=15.0 \mathrm{~Hz}, 1 \mathrm{H}, \mathrm{CHH}-\mathrm{C}_{6} \mathrm{H}_{2} \mathrm{~F}_{3}\right), 5.34\left(\mathrm{~d}, J_{\mathrm{HH}}=15.0 \mathrm{~Hz}, 1 \mathrm{H}, \mathrm{CH}-\mathrm{C}_{6} \mathrm{H}_{2} \mathrm{~F}_{3}\right), 4.00$ $\left(\mathrm{s}, 3 \mathrm{H}, \mathrm{NCH}_{3}\right), 1.69\left(\mathrm{~s}, 15 \mathrm{H}, \mathrm{CCH}_{3}\right) \cdot{ }^{13} \mathrm{C}\left\{{ }^{1} \mathrm{H}\right\} \mathrm{NMR}\left(\mathrm{CDCl}_{3}, 400 \mathrm{MHz}\right): \delta_{\mathrm{C}} 156.92$ $(\mathrm{CHNCH}=\mathrm{CHN}), 122.92,119.99(\mathrm{CHNCH}=\mathrm{CHN}$ and $\mathrm{CHNCH}=\mathrm{CHN}), 108.47,108.24$, 108.04, 101.21, 100.93, $100.65\left(\mathrm{C}_{6} \mathrm{H}_{2} \mathrm{~F}_{3}\right), 88.99\left(\mathrm{CCH}_{3}\right), 43.15\left(\mathrm{CH}_{2}-\mathrm{C}_{6} \mathrm{H}_{2} \mathrm{~F}_{3}\right), 38.86\left(\mathrm{NCH}_{3}\right)$, $9.13\left(\mathrm{CCH}_{3}\right) .{ }^{19} \mathrm{~F}\left\{{ }^{1} \mathrm{H}\right\} \mathrm{NMR}\left(\mathrm{CDCl}_{3}, 400 \mathrm{MHz}\right): \delta_{\mathrm{F}}-105.75\left(\mathrm{t}, J_{\mathrm{FF}}=8.0 \mathrm{~Hz}, 1 \mathrm{~F}\right.$, para-F), $109.87\left(\mathrm{~d}, J_{\mathrm{FF}}=8.0 \mathrm{~Hz}, 2 \mathrm{~F}\right.$, ortho-F). Anal. calcd. for $\mathrm{C}_{21} \mathrm{H}_{24} \mathrm{Cl}_{2} \mathrm{~F}_{3} \mathrm{IrN}_{2}: \mathrm{C}, 40.39 ; \mathrm{H}, 3.87 ; \mathrm{N}$, 4.49. Found: C, 39.61; H, 3.98; N, 4.26. HRMS: Clcd. $\mathrm{M}^{+} / \mathrm{Z}=598.12\left([\mathrm{M}-\mathrm{Cl}]^{+}\right)$. Found: $\mathrm{M}^{+} / \mathrm{Z}=589.1185\left([\mathrm{M}-\mathrm{Cl}]^{+}\right)$.

\section{Synthesis of 3-methyl-1-(2,6-dimethyl)benzylimidazolium bromide (BzMIm-} $\left.\mathbf{2} \mathrm{CH}_{3}\right)$.

1-methylimidazole $(0.410 \mathrm{~g}, 5.0 \mathrm{mmol})$ was added to a dichloromethane $(30.0 \mathrm{~mL})$ solution of 2,6-dimethylbenzyl bromide (1.100 g, $5.5 \mathrm{mmol})$. The resulting solution was stirred for 48 hours. The solution, initially colourless, turned opaque during the course of the

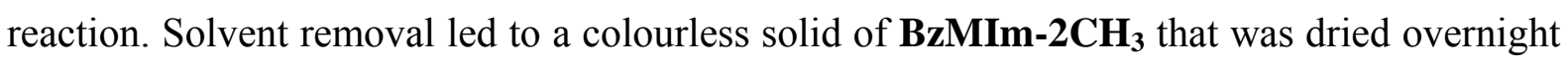
(1.400 g; yield 99 \%). BzMIm-2 $\mathbf{C H}_{3}$ was recrystallised by diffusing diethyl ether (ca. 4.5 $\mathrm{mL}$ ) into a dichloromethane (ca. $0.5 \mathrm{~mL})$ solution of $\mathbf{B z M I m}-\mathbf{2} \mathbf{C H}_{3}(0.5 \mathrm{~g}, 1.7 \mathrm{mmol}) .{ }^{1} \mathrm{H}$ NMR $\left(\mathrm{CDCl}_{3}, 400 \mathrm{MHz}\right): \delta_{\mathrm{H}} 10.64(\mathrm{~s}, 1 \mathrm{H}, \mathrm{NCHN}), 7.27$ (br s, $\left.1 \mathrm{H}, \mathrm{NCH}=\mathrm{CHN}\right), 7.23$ (br s, $1 \mathrm{H}, \mathrm{NCH}=\mathrm{CHN}), 7.12\left(\mathrm{~m}, 2 \mathrm{H}, \mathrm{C}_{6}\left(\mathrm{CH}_{3}\right)_{2} \mathrm{H}_{3}\right), 6.82$ (br s, $\left.1 \mathrm{H}, \mathrm{C}_{6}\left(\mathrm{CH}_{3}\right)_{2} \mathrm{H}_{3}\right), 5.62(\mathrm{~s}, 2 \mathrm{H}$, $\left.\mathrm{CH}_{2}\right), 4.13\left(\mathrm{~s}, 3 \mathrm{H}, \mathrm{NCH}_{3}\right), 2.34\left(\mathrm{~s}, 6 \mathrm{H}, \mathrm{CCH}_{3}\right) \cdot{ }^{13} \mathrm{C}\left\{{ }^{1} \mathrm{H}\right\} \mathrm{NMR}\left(\mathrm{CDCl}_{3}, 400 \mathrm{MHz}\right): \delta_{\mathrm{C}}$ $138.49(\mathrm{CHNCH}=\mathrm{CHN}), 131.05,130.31,130.20,129.42\left(\mathrm{C}_{6}\left(\mathrm{CH}_{3}\right)_{2} \mathrm{H}_{3}\right), 123.06,120.68$ $(\mathrm{CHNCH}=\mathrm{CHN}$ and $\mathrm{CHNCH}=\mathrm{CHN}), 48.29\left(\mathrm{CH}_{2}\right), 37.13\left(\mathrm{NCH}_{3}\right), 20.12\left(\mathrm{CCH}_{3}\right)$. Anal. calcd. for $\mathrm{C}_{13} \mathrm{H}_{17} \mathrm{BrN}_{2}$ : C, 55.53; H, 6.09; N, 9.96. Found: C, 55.58; H, 5.56; N, 10.53 . HRMS: Clcd. $\mathrm{M}^{+} / \mathrm{Z}=201.14\left(\left[\mathrm{M}^{+}\right]\right)$. Found: $\mathrm{M}^{+} / \mathrm{Z}=201.1386\left(\left[\mathrm{M}^{+}\right]\right)$. 
Synthesis of $\eta^{5}$-pentamethylcyclopentadienyl-iridium(3-methyl-1-(2,6-dimethyl)-

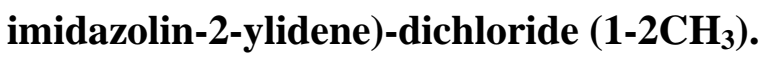

$\mathrm{Ag}_{2} \mathrm{O}(0.066 \mathrm{~g}, 0.3 \mathrm{mmol})$ was added, in the absence of light, to a dichloromethane (20.0 mL) solution of BzMIm-2 $\mathbf{C H}_{3}(0.105 \mathrm{~g}, 0.4 \mathrm{mmol})$. The resulting mixture was stirred at room temperature for 1 hour. $\left[\mathrm{Cp}^{*} \mathrm{IrCl}_{2}\right]_{2}(0.153 \mathrm{~g}, 0.2 \mathrm{mmol})$ was then added and the resulting mixture was stirred for 4 hours. The solution was then filtered through decalite, washing the residue with dichloromethane $(2 \times 20.0 \mathrm{~mL})$. Solvent removal from the collected dichloromethane solution led to the isolation of an orange crystalline powder of crude 12CH $\mathbf{C H}_{3}$. Recrystallisation from $\mathrm{CH}_{2} \mathrm{Cl}_{2}(5.0 \mathrm{~mL})$ and pentane $(10.0 \mathrm{~mL})$ led to the precipitation of an orange solid. After decanting the solvent, the solid was washed with pentane $(3 \times 20.0$ $\mathrm{mL})$, and then dried under vacuum, resulting in a pale orange powder of $\mathbf{1 - 2} \mathbf{C H}_{3}(0.185 \mathrm{~g}$; yield $76 \%$ ). ${ }^{1} \mathrm{H}$ NMR $\left(\mathrm{CDCl}_{3}, 400 \mathrm{MHz}\right): \delta_{\mathrm{H}} 7.09$ (d, $\left.1 \mathrm{H}, \mathrm{NCH}=\mathrm{CHN}\right), 7.07$ (d, $1 \mathrm{H}$, $\mathrm{NCH}=\mathrm{CHN}), 6.75\left(\mathrm{~m}, 2 \mathrm{H}, \mathrm{C}_{6}\left(\mathrm{CH}_{3}\right)_{2} \mathrm{H}_{3}\right), 6.24\left(\mathrm{t}, 1 \mathrm{H}, \mathrm{C}_{6}\left(\mathrm{CH}_{3}\right)_{2} \mathrm{H}_{3}\right), 5.29(\mathrm{~d}, 1 \mathrm{H}, \mathrm{CHH}), 4.73$ $(\mathrm{d}, 1 \mathrm{H}, \mathrm{CHH}), 3.99\left(\mathrm{~s}, 3 \mathrm{H}, \mathrm{NCH}_{3}\right), 2.30\left(\mathrm{~s}, 6 \mathrm{H}, \mathrm{CCH}_{3}\right), 1.69\left(\mathrm{~s}, 15 \mathrm{H}, \mathrm{CCH}_{3}\right) .{ }^{13} \mathrm{C}\left\{{ }^{1} \mathrm{H}\right\}$ $\mathrm{NMR}\left(\mathrm{CDCl}_{3}, 400 \mathrm{MHz}\right): \delta_{\mathrm{C}} 155.33(\mathrm{CHNCH}=\mathrm{CHN}), 131.57,129.18,128.89,128.25$, $125.04\left(\mathrm{C}_{6}\left(\mathrm{CH}_{3}\right)_{2} \mathrm{H}_{3}\right), 122.14,120.21(\mathrm{CHNCH}=\mathrm{CHN}$ and $\mathrm{CHNCH}=\mathrm{CHN}), 88.80\left(\mathrm{Cp}^{*}\right.$ $\left.\mathrm{CCH}_{3}\right), 48.82\left(\mathrm{CH}_{2}\right), 39.01\left(\mathrm{NCH}_{3}\right), 20.45\left(\mathrm{C}_{6}\left(\mathrm{CH}_{3}\right)_{2} \mathrm{H}_{3}\right), 9.56\left(\mathrm{Cp}^{*}-\mathrm{CCH}_{3}\right)$. HRMS: Clcd. $\mathrm{M}^{+} / \mathrm{Z}=568.22\left(\left[\mathrm{M}^{+}\right]\right)$. Found: $\mathrm{M}^{+} / \mathrm{Z}=568.2189\left(\left[\mathrm{M}^{+}\right]\right)$.

Hydrogen transfer initiated dehydration (HTID) of 1,3-propanediol (1,3-PDO) in the presence of $\mathrm{Cp}^{*} \mathrm{IrX}_{2}(\mathrm{NHC})$ complexes.

HTID of 1,3-PDO in the presence of (A) 1-3F or (B) 1-2CH and a base, in ionic liquid: screening reaction conditions.

1,3-PDO [see 1,3-PDO in (A) Table S1 or (B) Table S8], 1-3F (see 1-3F in Table S1) (A) or 1-2 $\mathbf{C H}_{3}$ (see 1-2CH in Table S8) (B), a base (A: see Base in Table S1; B: see $\mathrm{K}_{2} \mathrm{CO}_{3}$

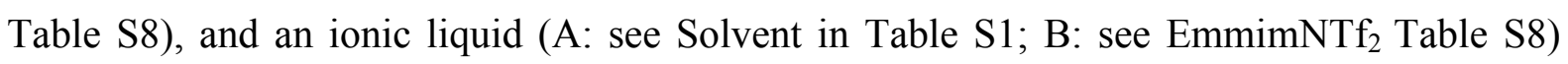
were added to a $50 \mathrm{~mL}$ round bottom flask connected, through a distillation condenser, to a $50 \mathrm{~mL}$ glass tube. The mixture was reacted at the selected temperature (see $\mathrm{T}$ in (A) Table S1 or (B) Table S8), at a controlled pressure of ca. 0.350 bar, for six hours, stirring at $1000 \mathrm{rpm}$. The reaction product, a colourless liquid, was isolated by distillation, and was collected for the duration of the six hours reaction in the collecting glass tube kept at ca. $-196{ }^{\circ} \mathrm{C}\left(\mathrm{N}_{2}(\mathrm{l})\right.$ bath). After separation from the minor water layer (if collected), the crude product [see \% 
yield (based on 2) in (A) Table S1 or (B) Table S8] was analysed by GC/MS [see (A) Table S11 or (B) Table S18] and ${ }^{1}$ H NMR [see (A) Table S21 or (B) Table S28] spectroscopies. The reacted mixture, left in the $50 \mathrm{~mL}$ round bottom flask, was analysed by ${ }^{1} \mathrm{H}$ NMR spectroscopy. $^{28}$

\section{Recycling experiments.}

HTID of 1,3-PDO in the presence of $1-3 F$ and $\mathrm{K}_{2} \mathrm{CO}_{3}$, at 120 or $150{ }^{\circ} \mathrm{C}$, in EmmimNTf $_{2}$, and at [1,3-PDO]:[Ir] $\cong 75.0$ or 220.0: 10 or 5 runs recycling experiments. $\left(\mathrm{A}: \mathrm{T}=150{ }^{\circ} \mathrm{C},[1,3-\mathrm{PDO}]:[\mathrm{Ir}] \cong 75.0 ; \mathrm{B}: \mathrm{T}=120^{\circ} \mathrm{C},[1,3-\mathrm{PDO}]:[\operatorname{Ir}] \cong 75.0 ; \mathrm{C}: \mathrm{T}=150\right.$ ${ }^{\circ} \mathrm{C}$, [1,3-PDO]:[Ir] $\cong 220.0$.)

1,3-PDO [see 1,3-PDO in entry 1 in (A) tables S2, S3 and S4, (B) tables S5 and S6, (C) table S7], 1-3F [see 1-3F in entry 1 in (A) tables S2, S3 and S4, (B) tables S5 and S6, (C) table S7], $\mathrm{K}_{2} \mathrm{CO}_{3}$ [see $\mathrm{K}_{2} \mathrm{CO}_{3}$ in entry 1 in (A) tables $\mathrm{S} 2$, S3 and $\mathrm{S} 4$, (B) tables S5 and S6, (C) table S7], and EmmimNTf [see EmmimNTf $_{2}$ in entry 1 in (A) tables S2, S3 and S4, (B) tables $\mathrm{S} 5$ and $\mathrm{S} 6,(\mathrm{C})$ table $\mathrm{S} 7$ ], were mixed in a $50 \mathrm{~mL}$ round bottom flask and reacted at (A, C) $150{ }^{\circ} \mathrm{C}$ or (B) $120^{\circ} \mathrm{C}$, using the same glassware apparatus, procedure and conditions as those described above for the screening reaction conditions experiments. The crude product [see \% Yield (based on 2) in entry 1 in (A) tables S2, S3 and S4, (B) tables S5 and S6, (C) table S7] was analysed by GC/MS [see entry 1 in (A) tables S12, S13 and S14, (B) tables S15 and S16, (C) Table S17] and ${ }^{1}$ H NMR [see entry 1 in (A) tables S22, S23 and S24, (B) tables S25 and S26, (C) Table S27] spectroscopies. The reacted mixture, left in the $50 \mathrm{~mL}$ round bottom flask, was analysed by ${ }^{1} \mathrm{H}$ NMR spectroscopy. The following 9 or 4 (for the 10 and 5 runs recycling experiments, respectively) recycling experiments were carried out as follows: 1,3-PDO [see 1,3-PDO in (A) (10 runs recycling) entries 2-10 in tables S2 and S3, and (5 runs recycling) entries 2-5 in table S4, (B) (10 runs recycling) entries 2-10 in Table S5, and (5 runs recycling) entries 2-5 in Table S6, (C) (5 runs recycling) entries 2-5 in Table S7] and $\mathrm{K}_{2} \mathrm{CO}_{3}$ [see $\mathrm{K}_{2} \mathrm{CO}_{3}$ in (A) (10 runs recycling) entries 2-10 in tables $\mathrm{S} 2$ and $\mathrm{S} 3$, and (5 runs recycling) entries 2-5 in Table $\mathrm{S} 4$, (B) (10 runs recycling) entries 2-10 in Table S5, and (5 runs recycling) entries 2-5 in Table S6, (C) (5 runs recycling) entries 2-5 in Table S7] were added to the reacted mixture resulting from the previous recycling experiment, in the $50 \mathrm{~mL}$

28 The succesful isolation of highly pure 2 from the crude product via distillation at atmospheric pressure, at $\mathrm{T}$ $\cong 43{ }^{\circ} \mathrm{C}$, has been proven when testing the HTID of 1,3-PDO in the presence of 1-5H (see Scheme 2). See Y.M. Wang, F. Lorenzini, M. Rebros, G.C. Saunders, A.C. Marr, Green Chem. 18 (2016) 1751. 
round bottom flask. The resulting mixture was reacted, and then analysed, as in the first cycle.

HTID of 1,3-PDO in the presence of $1-3 \mathrm{~F}$ and $\mathrm{K}_{2} \mathrm{CO}_{3}$, and mercury, in EmmimNTf $_{2}$.

1,3-PDO (see 1,3-PDO in Table S9), 1-3F (see 1-3F in Table S9), $\mathrm{K}_{2} \mathrm{CO}_{3}$ (see $\mathrm{K}_{2} \mathrm{CO}_{3}$ in Table S9), mercury (three drops), and EmmimNTf (see EmmimNTf $_{2}$ in Table S9) were mixed in a $50 \mathrm{~mL}$ round bottom flask and reacted at $150{ }^{\circ} \mathrm{C}$, using the same glassware apparatus, procedure and conditions as those described above for the reactions in the absence of mercury. The crude product (see \% yield (based on propionaldehyde (2) in Table S9) was analysed by GC/MS (Table S19) and ${ }^{1}$ H NMR (Table S29) spectroscopies.

HTID of 1,3-PDO in the presence of 1-3F and $\mathrm{K}_{2} \mathrm{CO}_{3}$, and water, in EmmimNTf

1,3-PDO (see 1,3-PDO in Table S10), 1-3F (see 1-3F in Table S10), $\mathrm{K}_{2} \mathrm{CO}_{3}$ (see $\mathrm{K}_{2} \mathrm{CO}_{3}$ in Table S10), water $\left(3.0 \mathrm{~mL}\right.$ ), and EmmimNTf (see EmmimNTf $_{2}$ in Table S10) were mixed in a $50 \mathrm{~mL}$ round bottom flask and reacted at $150{ }^{\circ} \mathrm{C}$, using the same glassware apparatus, procedure and conditions as those described above for the reactions in the absence of water. The monophasic crude product was analysed by GC/MS (Table S20) and ${ }^{1} \mathrm{H}$ NMR (Table S30) spectroscopies.

Analysis of reaction product solutions of HTID of 1,3-PDO in the presence of 1-3F and a base, in ionic liquids: general methodology.

GC/MS spectroscopy allowed calculation of the amount of 5 in the isolated crude product solutions. The molar amount of 2, 3 and $\mathbf{4}$, relative to 5 , was then calculated via integration of the ${ }^{1} \mathrm{H}$ NMR spectrum of the isolated crude product solutions. Then, the amount of 2, 3 and $\mathbf{4}$ in the isolated crude product solutions, and ultimately mass balance, was calculated by combining GC/MS and ${ }^{1} \mathrm{H}$ NMR spectroscopic information.

The GC/MS and ${ }^{1} \mathrm{H}$ NMR analyses of the reaction product solutions are hereby described.

GC/MS analysis of reaction product solutions. 


\section{- $\mathrm{CH}_{3} \mathrm{CH}_{2} \mathrm{CH}_{2} \mathrm{OH} / \mathrm{CDCl}_{3} / \mathrm{CH}_{3} \mathrm{OH}$ calibration.}

The substrate and internal standard $\mathrm{CH}_{3} \mathrm{OH}$ solutions for calibration were prepared and then analysed by GC/MS spectroscopy according to the method that this group recently reported, ${ }^{14}$ leading to the following calibration curve:

$$
y=0.4449 x-0.0345\left(R^{2}=0.9938\right)\left(x=C_{5} / C_{6}, y=A_{5} / A_{6}\right) .
$$

\section{- GC analysis of $\mathrm{CH}_{3} \mathrm{OH}$ solutions of pure 2, 3, 4, and 5.}

Commercially available 2, 3, 4, and 5 (ca. $0.005 \mathrm{~g}$ ) were each dissolved in $\mathrm{CH}_{3} \mathrm{OH}$ (1.0 $\mathrm{mL}$ ). The resulting solutions were analysed by GC/MS spectroscopy. The resulting spectra ${ }^{14}$ were used as benchmarks in the GC/MS analysis of the reaction product solutions resulting from screening conditions experiments and catalyst recycling experiments.

- General methodology for screening conditions and catalyst recycling experiments.

A $\mathrm{CH}_{3} \mathrm{OH}(1.0 \mathrm{~mL})$ solution of a known amount of the reaction product solutions (PS in tables S11, S12, S13, S14, S15, S16, S17, S18, S19, S20) was prepared. The internal standard $\mathrm{CDCl}_{3}$ (6 in tables S11, S12, S13, S14, S15, S16, S17, S18, S19, S20) was added. The resulting solution was analysed by GC/MS spectroscopy. The areas of the peaks due to the substrate $\left(\mathrm{A}_{5}\right)$ and the internal standard $\left(\mathrm{A}_{6}\right)$ are reported, for each solution, in tables $\mathrm{S} 11$, S12, S13, S14, S15, S16, S17, S18, S19, S20. Equation Eq. 1 then allowed calculation of [5] $\left(C_{5}\right)$. Entries 1-39 in Table S11, 1-10 in Table S12, 1-10 in Table S13, 1-5 in Table S14, 1-10 in Table S15, 1-5 in Table S16, 1-5 in Table S17, 1-2 in Table S18, entry 1 in Table S19 and entry 1 in Table S20 correspond to entries 1-39 in tables 1, S1, and S21, 1-10 in tables S2, S22, and S31, 1-10 in tables S3, S23, and S32, 1-5 in tables S4, S24, and S33, 1-10 in tables S5, S25, and S34, 1-5 in tables S6, S26, and S35, 1-5 in tables S7, S27, and S36, 1-2 in tables S8, S28, and 3, entry 1 in tables S9, S29, and 2, and entry 1 in tables S10, S30, and S37, respectively.

\section{${ }^{1}$ H NMR analysis of reaction product solutions: general procedure.}

$\mathrm{A} \mathrm{CDCl}_{3}(\mathrm{ca} .0 .7 \mathrm{~mL})$ solution of the reaction product solutions (ca. $\left.0.010 \mathrm{~g}\right)$ was prepared. The resonances due to the four main components $\mathbf{2}, \mathbf{3}, \mathbf{4}$, and $\mathbf{5}\left(\mathbf{2}, \delta_{\mathrm{H}} 9.78(\mathrm{C}(\mathrm{O}) \mathrm{H}\right.$,

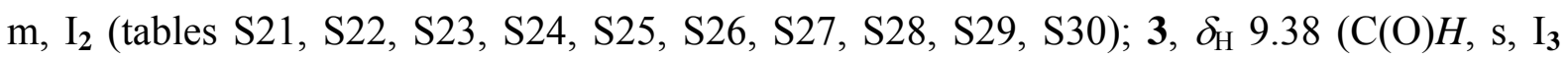


(tables S21, S22, S23, S24, S25, S26, S27, S28, S29, S30)); 4, $\delta_{\mathrm{H}} 9.60\left(\mathrm{C}(\mathrm{O}) H, \mathrm{~d}, J_{\mathrm{HH}}=2.02\right.$ $\mathrm{Hz}, \mathrm{I}_{4}\left(\right.$ tables S21, S22, S23, S24, S25, S26, S27, S28, S29, S30)); 5, $\delta_{\mathrm{H}} 3.60\left(\mathrm{CH}_{2} \mathrm{OH}, \mathrm{t}, J_{\mathrm{HH}}\right.$ $=6.64 \mathrm{~Hz}, \mathrm{I}_{5}$ (tables S21, S22, S23, S24, S25, S26, S27, S28, S29, S30))) were investigated in the ${ }^{1} \mathrm{H}$ NMR spectrum of the resulting solutions. The normalised ratio of $\mathrm{I}_{2}, \mathrm{I}_{3}, \mathrm{I}_{4}$ and $\mathrm{I}_{5}$ allowed calculation of the molar ratio of $2,3,4$, and 5 , and ultimately the molar yield of 2,3 , 4, and 5 (tables S21, S22, S23, S24, S25, S26, S27, S28, S29, S30), and the mass balance (MB) (tables S21, S22, S23, S24, S25, S26, S27, S28, S29, S30). 


\section{Results and discussion.}

This group has recently reported the successful synthesis of propionaldehyde, in high yields and selectivities, via hydrogen transfer initiated dehydration (HTID) of 1,3propanediol (1,3-PDO) in the presence of a $\mathrm{Cp}^{*} \mathrm{IrCl}_{2}(\mathrm{NHC})$ complex and a base, in ionic liquids as the solvent media. ${ }^{14}$ The HTID of 1,3-PDO in ionic liquids was found to be successful also in the presence of water, and air. Complex 1-5H (Scheme 2) was found to be a highly recyclable catalyst precursor for the selective production of a range of C3 and C6 aldehydes. Highly pure propionaldehyde was successfully isolated under reduced pressure, and distillation, with production of minimal waste. The ionic liquid solutions of 1,3-PDO mimic the ionic liquid solutions produced by extraction of aqueous glycerol fermentation broths: the successful synthesis and isolation of a value-added chemical such as propionaldehyde from them represents the valorisation of waste to chemicals. The combination of $\mathrm{Cp}^{*} \mathrm{IrX}_{2}(\mathrm{NHC})$ catalysed HTID of 1,3-PDO in ionic liquids with bio-catalysis has then, ultimately, the potential to allow the transformation of waste glycerol into valuable chemicals that can be simply isolated.

The high activity, selectivity, and recyclability displayed by the catalyst precursor 1-5H prompted us to investigate how the performance of $\mathrm{Cp}^{*} \operatorname{IrX}_{2}(\mathrm{NHC})$ complexes as catalyst precursors for HTID of 1,3-PDO could be maximised. The possible involvement of C-H activation occurring at the benzylic ortho-C in $\mathbf{1 - 5 H}$, and cyclometallation, ${ }^{29}$ had to be considered, along with their possible, beneficial or detrimental, contribution to catalysis. Replacing then the $\mathrm{C}-\mathrm{H}$ bond at the benzylic ortho- $\mathrm{C}$ in $\mathbf{1 - 5 H}$ with the much stronger $\mathrm{C}-\mathrm{F}$ bond $^{30}$ could have a significant effect on the catalytic activity of the $\mathrm{Cp}^{*} \operatorname{IrX}_{2}(\mathrm{NHC})$ complexes as catalyst precursors. Furthermore, replacing the $\mathrm{C}-\mathrm{H}$ bond with a $\mathrm{C}-\mathrm{C}$ bond would prevent ortho-C-X bond activation, and any orthometallation reactions.

29 (a) H.P. Thomas, Y.-M. Wang, F. Lorenzini, S.J. Coles, P.N. Horton, A.C. Marr, G.C. Saunders, Organometallics 36 (2017) 960; (b) M. Moselage, J. Li, L. Ackermann, ACS Catal. 6 (2016) 498; (c) P.B. Arockiam, C. Bruneau, P.H. Dixneuf, Chem. Rev. 112 (2012) 5879; (d) L. Keyes, A.D. Sun, J.A. Love, Eur. J. Org. Chem. (2011) 3985; (e) F. Lorenzini, P. Marcazzan, B.O. Patrick, B.R. James, Can. J. Chem. 86 (2008) 253; (f) M. Martín, E. Sola, S. Tejero, J.L. Andrés, L.A. Oro, Chem. Eur. J. 12 (2006) 4043; (g) X. Li, H. Sun, F. Yu, U. Flörke, H.-F. Klein, Organometallics 25 (2006) 4695; (h) E. Fernandez, A. Ruiz, C. Claver, S. Castillon, P.A. Chaloner, P.B. Hitchcock, Inorg. Chem. Comm. 2 (1999) 21; (i) O. López, M. Crespo, M. Font-Bardia, X. Solans, Organometallics 16 (1997) 1233; (j) S.D. Perera, B.L. Shaw, M. Thornton-Pett, Inorg. Chim. Acta 233 (1995) 103; (k) M. Crespo, M. Martinez, J. Sales, Organometallics 12 (1993) 4297; (l) C.M. Anderson, M. Crespo, G. Ferguson, A.J. Lough, R.J. Puddephat, Organometallics 11 (1992) 1177; (m) C.M. Anderson, R.J. Puddephat, G. Ferguson, A.J. Lough, J. Chem. Soc., Chem. Comm. (1989) 1297; (n) T.G. Richmond, C.E. Osterberg, A.M. Arif, J. Am. Chem. Soc. 109 (1987) 8091; (o) M.I. Bruce, R.C.F. Gardner, F.G.A. Stone, J. Chem. Soc., Dalton Trans. (1976) 81; (p) M.I. Bruce, B.L. Goodall, G.L. Sheppard, F.G.A. Stone, J. Chem. Soc. Dalton Trans. (1975) 591; (q) M.I. Bruce, R.C.F. Gardner, B.L. Goodall, F.G.A. Stone, R.J. Doedens, J.A. Moreland, J. Chem. Soc., Chem. Comm. (1974) 185.

30 (a) T. Zheng, J. Li, S. Zhang, B. Xue, H. Sun, X. Li, O. Fuhr, D. Fenske, Organometallics 35 (2016) 3538; (b) Y. Nakao, N. Kashihara, K.S. Kanyiva, T. Hiyama, J. Am. Chem. Soc. 130 (2008) 16170. 
Synthesis of benzyl-imidazolium compounds BzMIm-3F and BzMIm-2CH , and of

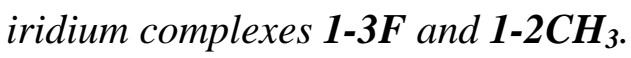

The complexes 1-3F (see Scheme 1), in which both the benzylic ortho-C-H bonds have

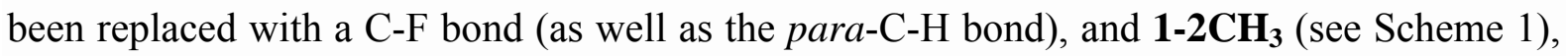
in which both the ortho-C-H bonds have been replaced with two $\mathrm{C}-\mathrm{CH}_{3}$ bonds, were then synthesised, and their activity as catalyst precursors for HTID of 1,3-PDO in ionic liquids was tested. In addition, the substituents were chosen to have opposite effects on the overall electron density at the metal. The presence of three fluorine atoms on the benzyl arm of the carbene ligand bound to the metal centre in 1-3F could allow a first test of how diminishing the electronic density on the metal centre would affect the catalytic activity of $\mathrm{Cp} * \mathrm{IrCl}_{2}(\mathrm{NHC})$ complexes towards HTID of 1,3-PDO. Incorporating methyl functionality would increase the electron density.

\section{Synthesis of BzMIm-3F and BzMIm-2 $\mathrm{CH}_{3}$.}

Scheme 1 depicts the preparation of benzyl-imidazolium compounds BzMIm-3F and BzMIm-2 $\mathbf{C H}_{3}$, and then of the iridium complexes 1-3F and 1-2 $\mathbf{C H}_{3}$.

BzMIm-3F and BzMIm-2 $\mathbf{C H}_{3}$ were synthesised following the synthetic procedure reported in the literature for analogous benzyl-imidazolium compounds. ${ }^{31}$ BzMIm-3F and BzMIm-2 $\mathbf{C H}_{3}$ were isolated in excellent yields as air- and moisture-stable, crystalline solids after purification.

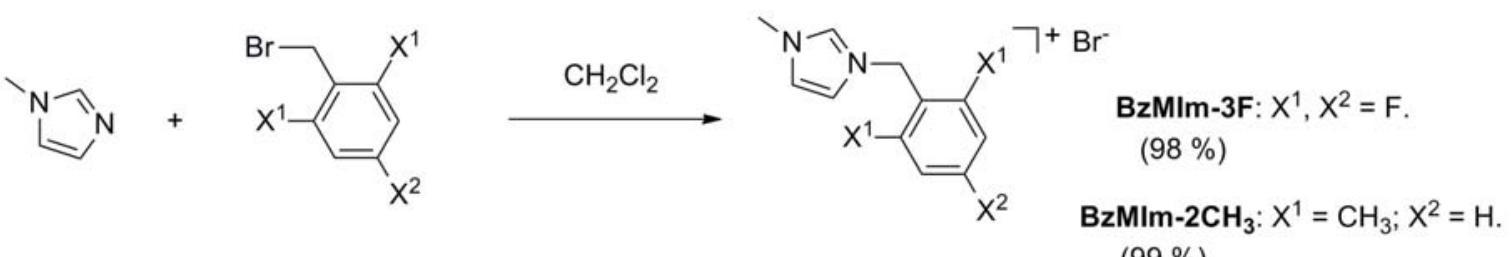
(99\%)

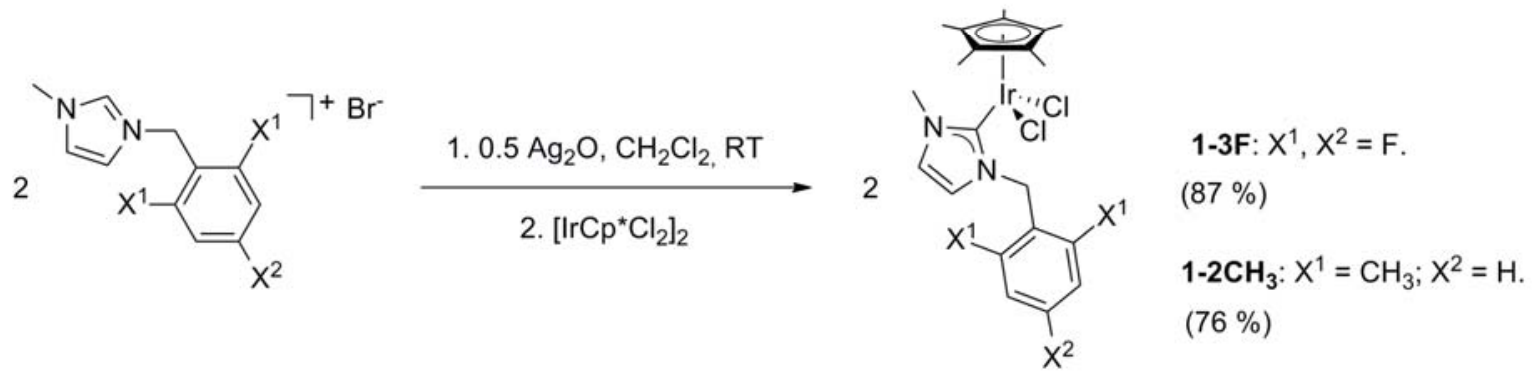

31 (a) Y. Gothe, T. Marzo, L. Messori, N. Metzler-Nolte, Chem. Eur. J. 22 (2016) 12487; (b) P.V. Simpson, K. Radacki, H Braunschweig, U. Schatzschneider, J. Organomet. Chem. 782 (2015) 116; (c) S. McGrandle, G.C. Saunders, J. Fluor. Chem. 126 (2005) 451. 
Scheme 1. Synthesis of benzyl-imidazolium ligand precursors BzMIm-3F and BzMIm-2CH $\mathbf{H}_{3}$ and $\mathrm{Cp}^{*} \mathrm{IrCl}_{2}(\mathrm{NHC})$ complexes $\mathbf{1 - 3 F}$ and $\mathbf{1 - 2} \mathbf{C H}_{3}$, via transmetalation of imidazolylidene ligands from silver carbene derivatives to $\left[\mathrm{Cp}^{*} \mathrm{IrCl}_{2}\right]_{2}$.

BzMIm-3F was synthesised by reacting 1-methylimidazolium with $(2,4,6-$ trifluoro)benzyl bromide in dichloromethane, under ambient pressure and at room temperature, for 24 hours. ${ }^{31}$ Highly pure BzMIm-3F was isolated in high yield (98\%) as a colourless crystalline solid (see Scheme 1). ${ }^{1} \mathrm{H},{ }^{19} \mathrm{~F}\left\{{ }^{1} \mathrm{H}\right\}$, and ${ }^{13} \mathrm{C}\left\{{ }^{1} \mathrm{H}\right\}$ NMR spectra of solutions of isolated BzMIm-3F show resonances typical of reported, analogous benzyl imidazolium compounds. ${ }^{31}$ The ${ }^{1} \mathrm{H}$ NMR spectrum of deuterated methanol solutions of isolated BzMIm-3F displays peaks that fall in the typical range for imidazolium $\mathrm{C} 4$ and $\mathrm{C} 5$ protons $\left(\delta_{\mathrm{H}} 7.68,7.66\right)$, benzylic protons $\left(\delta_{\mathrm{H}} 5.58\right), N$-methylic protons $\left(\delta_{\mathrm{H}} 3.98\right)$, and aromatic protons $\left(\delta_{\mathrm{H}} 7.11\right)$. The resonance due to the imidazolic $\mathrm{C} 2$ proton could only be detected in the deuterated choloroform solutions of BzMIm-3F $\left(\delta_{\mathrm{H}} 10.52\right)$. The ${ }^{19} \mathrm{~F}\left\{{ }^{1} \mathrm{H}\right\}$ NMR spectrum shows the typical resonances due to the para fluorine atom and the two ortho fluorine atoms in the benzylic aromatic ring ( $\delta_{\mathrm{F}}-105.69$ and -112.90 , respectively). Peaks falling in the typical range for aromatic and imidazolic $\left(\delta_{\mathrm{C}} 166.89-102.42\right)$, benzylic $\left(\delta_{\mathrm{C}}\right.$ 41.67), and N-methylic ( $\left.\delta_{\mathrm{C}} 36.91\right)$ carbon atoms are observed in the ${ }^{13} \mathrm{C}\left\{{ }^{1} \mathrm{H}\right\} \mathrm{NMR}$ spectrum of deuterated methanol solutions of BzMIm-3F.

The method described for the synthesis of BzMIm-3F also allowed isolation of highly pure BzMIm-2 $\mathbf{C H}_{3}$, in high yield (99\%), as a colourless powder, from 1-methylimidazole and 2,6-dimethylbenzyl bromide (see Scheme 1). The resonances displayed in the ${ }^{1} \mathrm{H}$ NMR

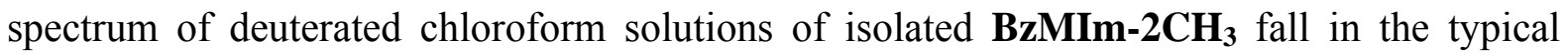
range for imidazolic $\mathrm{C} 2$ protons $\left(\delta_{\mathrm{H}} 10.64\right)$, imidazolium $\mathrm{C} 4$ and $\mathrm{C} 5$ protons $\left(\delta_{\mathrm{H}} 7.27,7.23\right)$, aromatic protons $\left(\delta_{\mathrm{H}} 7.12,6.82\right)$, benzylic protons $\left(\delta_{\mathrm{H}} 5.62\right)$, and $N-\left(\delta_{\mathrm{H}} 4.13\right)$ and $C$-methylic ( $\left.\delta_{\mathrm{H}} 2.34\right)$ protons. ${ }^{31}$ The ${ }^{13} \mathrm{C}\left\{{ }^{1} \mathrm{H}\right\}$ NMR spectrum exhibits peaks typical for aromatic and imidazolic $\left(\delta_{\mathrm{C}} 138.49-120.68\right)$, benzylic $\left(\delta_{\mathrm{C}} 48.29\right)$, and $N-\left(\delta_{\mathrm{C}} 37.13\right)$ and $C$-methylic $\left(\delta_{\mathrm{C}}\right.$ 20.12) carbon atoms. ${ }^{31}$

\section{Synthesis of 1-3F and 1-2 $\mathrm{CH}_{3}$.}

1-3F and 1-2CH 3 were then synthesised, following the synthetic procedure reported in the literature for analogous $\mathrm{Cp}^{*} \mathrm{IrCl}_{2}(\mathrm{NHC})$ complexes, by transmetalation of 3-methyl-1(2,4,6-trifluorobenzyl)-imidazolylidene and 3-methyl-1-(2,6dimethyl)benzylimidazolylidene, respectively, from the corresponding silver carbene derivative to $\left[\mathrm{Cp}^{*} \mathrm{IrCl}_{2}\right]_{2}$, in $\mathrm{CH}_{2} \mathrm{Cl}_{2}$ (see Scheme 1). The reactivity of Ag-NHC complexes towards NHC transfer has been reported for transmetalation reactions with $\operatorname{Rh}(\mathrm{I})$ and $\operatorname{Ir}(\mathrm{I})$ 
complexes, and was also found to apply to $\left[\mathrm{Cp}^{*} \mathrm{IrCl}_{2}\right]_{2} \cdot{ }^{31 \mathrm{c}, 32}$ Compounds $\mathbf{1 - 3} \mathbf{F}$ and $\mathbf{1 - 2} \mathbf{C H}_{\mathbf{3}}$ were isolated in good to excellent yields (87 and $76 \%$, respectively) as air- and moisturestable, crystalline solids after purification.

The ${ }^{1} \mathrm{H}$ and ${ }^{13} \mathrm{C}\left\{{ }^{1} \mathrm{H}\right\}$ NMR spectra of the deuterated chloroform solutions of both 1-3F and $\mathbf{1 - 2} \mathbf{C H}_{3}$ display the expected resonances, falling at chemical shifts consistent with those reported in the literature for analogous $\mathrm{Cp} * \operatorname{Ir}(\mathrm{NHC})$ complexes. ${ }^{32,33}$

No significant changes were observed regarding the chemical shift of the peaks corresponding to the aromatic and imidazolium methylic protons of 1-3F as compared to the reacting ligand (aromatic: $\delta_{\mathrm{H}}$ 6.76, vs. 6.78 in BzMIm-3F; $\mathrm{NCH}_{3}: \delta_{\mathrm{H}} 4.00$, vs. 4.15 in BzMIm-3F). The only resonance due to the two equivalent methylenic protons observed in BzMIm-3F, a singlet at $\delta_{\mathrm{H}} 5.65$, splits into two doublets at $\delta_{\mathrm{H}} 5.96$ and 5.34 in 1-3F: due to coordination, the benzylic arm of the NHC ligand loses its freedom of rotation, resulting in the inequivalence of the two $-\mathrm{NCH}_{2}$ - proton atoms. ${ }^{31}$ The resonances due to the two imidazolic $\mathrm{NCH}=\mathrm{CHN}$ protons were found to be significantly upshielded in $\mathbf{1 - 3 \mathbf { F }}\left(\delta_{\mathrm{H}} 6.87\right.$ and 6.48) compared to BzMIm-3F ( $\delta_{\mathrm{H}} 7.41$ and 7.19$)$ ) ${ }^{32,33}$ The peak due to the $\mathrm{Cp}^{*}$ proton atoms $\left(\delta_{\mathrm{H}} 1.69\right)$ falls in the range expected for $\mathrm{Cp}^{*} \mathrm{Ir}$ complexes reported in the literature. ${ }^{32,33}$ The resonances exhibited by the ${ }^{19} \mathrm{~F}\left\{{ }^{1} \mathrm{H}\right\}$ spectrum of the deuterated chloroform solutions of 1-3F, namely a triplet at $\delta_{\mathrm{F}}-105.75$, due to the para-fluorine atom, and the doublet at $\delta_{\mathrm{F}}-$ 109.87, due to the two ortho-fluorine atoms, are similar to those displayed by the ${ }^{19} \mathrm{~F}\left\{{ }^{1} \mathrm{H}\right\}$ spectrum of the deuterated methanol solutions of BzMIm-3F.

X-ray analysis of needle-shaped, single crystals of 1-3F, grown by diffusing $n$-pentane into $\mathrm{CHCl}_{3}$ solutions of $\mathbf{1 - 3 \mathbf { F }}$ has confirmed its structure. ${ }^{34}$ However, R-Factor $\cong 11.05 \%$ has prompted further, current work aimed at producing higher quality single crystals of 1-3F in order to refine its structure to acceptable $\mathrm{R}^{2}$ values.

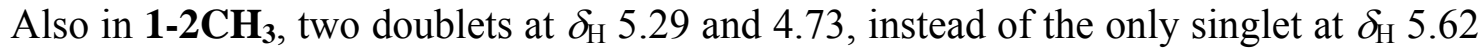
as in the free ligand precursor BzMIm-2 $\mathbf{C H}_{3}$, were observed for the two inequivalent $-\mathrm{NCH}_{2}$ methylenic protons. ${ }^{31}$ The rest of the resonances observed in the ${ }^{1} \mathrm{H}$ and ${ }^{13} \mathrm{C}\left\{{ }^{1} \mathrm{H}\right\} \mathrm{NMR}$ spectra of the deuterated chloroform solutions of $\mathbf{1 - 2} \mathbf{C H}_{3}$ are similar to those, previously discussed, of BzMIm-2 $\mathbf{C H}_{3}$, with the exception of that due to the coordinating carbene

32 (a) U. Hintermair, J. Campos, T.P. Brewster, L.M. Pratt, N.D. Schley, R.H. Crabtree, ACS Catal. 4 (2014) 99; (b) U. Hintermair, U. Englert, W. Leitner, Organometallics 30 (2011) 3726; (c) A.C. Marr, M. Nieuwenhuyzen, C.L. Pollock, G.C. Saunders, Organometallics 26 (2007) 2659; (d) R. Corberán, M. Sanaú, E. Peris, J. Am. Chem. Soc. 128 (2006) 3974.

33 (a) Z. Codolà, J.M.S. Cardoso, B. Royo, M. Costas, J. Lloret-Fillol, Chem. Eur. J. 19 (2013) 7203; (b) T.K. Maishal, J.-M. Basset, M. Boualleg, C. Copéret, L. Veyre, C. Thieuleux, Dalton Trans. (2009) 6956.

34 F. Lorenzini, F. Marchetti, A.C. Marr et al. (2016) unpublished results. 
carbon atom, that is deshielded to $\delta_{\mathrm{C}} 155.33$ in $\mathbf{1 - 2} \mathbf{C H}_{3}$, and with the addition of the signals due to the $\mathrm{Cp}^{*}$ carbon atoms at $\delta_{\mathrm{C}} 88.80\left(\mathrm{C}_{5}\right)$ and $9.56\left(\mathrm{CH}_{3}\right)$.

HTID of 1,3-PDO: catalytic tests using catalyst precursors $\mathbf{1 - 3 F}$ and $\mathbf{1 - 2} \mathbf{C H}_{3}$.

Complexes 1-3F and 1-2-CH 3 were then tested as catalyst precursors for HTID of 1,3PDO in ionic liquids.

\section{Testing catalyst precursor 1-3F.}

The treatment of 1,3-PDO with 1-3F and a base, in an ionic liquid (EmmimNTf Er $_{2}$ or $\mathrm{N}_{1,8,8,8} \mathrm{NTf}_{2}$ ) solution, was found to lead to a range of C3 and C6 alcohols and aldehydes (see Scheme 2): the major products observed were the C3 aldehyde propionaldehyde (2), and the C6 aldehydes 2-methyl-pentenal (3) and 2-methyl-pentanal (4), along with 1-propanol (5) as the major by-product (Scheme 2). The range of products is similar to that, recently reported by this group, observed when using $\mathbf{1 - 5 H}$ as the catalyst precursor. ${ }^{14}$

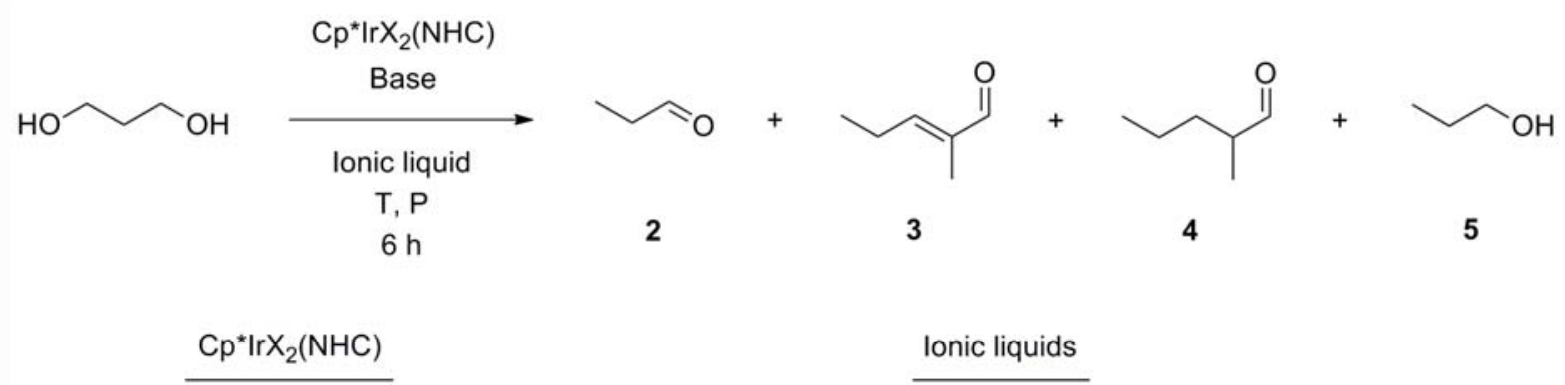

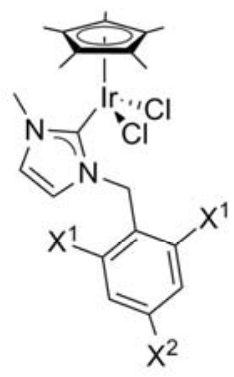

1-5H: $\mathrm{X}^{1}, \mathrm{X}^{2}=\mathrm{H}$

1-3F: $\mathrm{X}^{1}, \mathrm{X}^{2}=\mathrm{F}$; $1-2 \mathrm{CH}_{3}: \mathrm{X}^{1}=\mathrm{CH}_{3} ; \mathrm{X}^{2}=\mathrm{H}$.

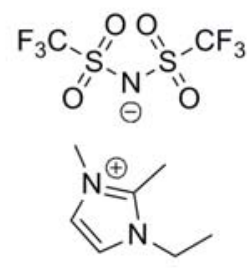

EmmimNTf $_{2}$

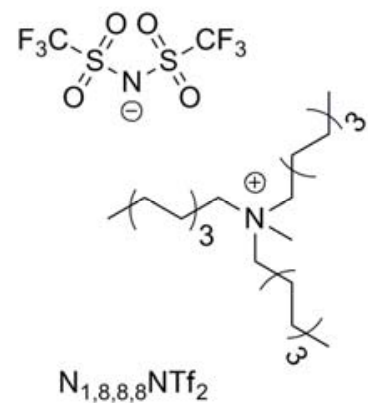

$\mathrm{N}_{1,8,8,8} \mathrm{NTf}_{2}$

Scheme 2. HTID of 1,3-PDO catalysed by $\mathrm{Cp}^{*} \mathrm{IrX}_{2}(\mathrm{NHC})$ complexes, in the presence of a base, in ionic liquids, at different temperatures and pressures: major reaction products; structure of the catalyst precursor complexes 1-5H, 1-3F and 1-2-CH , and of the ionic liquids EmmimNTf $f_{2}$ and $\mathrm{N}_{1,8,8,8} \mathrm{NTf}_{2}$ tested as the solvent media. 
The postulated reaction mechanism for the base-assisted HTID of 1,3-PDO catalysed by $\mathrm{Cp}^{*} \operatorname{IrX}_{2}(\mathrm{NHC})$ complexes is shown in Scheme 3. Formation of the target $\mathrm{C} 3$ aldehyde 2 occurs via the HTID of 1,3-PDO through the intermediates 3-hydroxypropionaldehyde and acrolein. Access to C6 chemistry occurs if $\mathbf{2}$ is allowed to further react after its formation: self-aldol-condensation of $\mathbf{2}$ yields, after dehydration, $\mathbf{3}$. Hydrogenation of $\mathbf{3}$ leads to $\mathbf{4}^{12,14}$ Both 2 and acrolein can undergo hydrogenation to the major by-product 5 . Further production of hydrogen could result from formaldehyde, formed, along with acetaldehyde, via the retroaldol condensation of the hydrogen transfer intermediate 3-hydroxypropionaldehyde, and dehydrogenation of alkyl chains to olefins; spectroscopic evidence supports formation of small quantities of acetaldehyde and olefins in the reaction solutions. Decarbonylation of aldehydes, deriving from dehydrogenation of primary alcohols, to shorter alkanic and alkenic chains should also be taken into account when assessing the possible products resulting from HTID of 1,3-PDO. B. Likozar and co-workers have investigated the hydrodeoxygenation (HDO) and cracking, in the presence of heterogeneous $\mathrm{NiMo} / \mathrm{Al}_{2} \mathrm{O}_{3},{ }^{35,36,37} \mathrm{MoS}_{2},{ }^{38,36} \mathrm{MoO}_{2},{ }^{38}$ $\mathrm{Mo}_{2} \mathrm{C},{ }^{38} \mathrm{WS}_{2},{ }^{38} \mathrm{Pd} / \mathrm{Al}_{2} \mathrm{O}_{3},{ }^{36}$ and $\mathrm{Pd} / \mathrm{C}^{39}$ catalysts, of levulinates ${ }^{39}$ produced by solvolysis of lignocellulosic biomass: while secondary alcoholic groups undergo, selectively, the HDO pathway to alkanes via dehydration followed by hydrogenation, primary alcoholic groups tend to rather dehydrogenate to the corresponding aldehydes; the following decarbonylation produces short chain alkenes.

Taking all the above into account, specific target compounds resulting from HTID of 1,3-PDO can be obtained by tuning the reaction conditions in order to maximise selectivity towards the target and minimise by-product formation. Running the HTID of 1,3-PDO in ionic liquids under vacuum allows removal of 2 from the reaction mixture as soon as it is formed, minimising the occurrence of the side-reactions leading to 3,4 and 5 , and so providing crude products rich in the target $\mathrm{C} 3$ aldehyde 2. Operating the reaction, instead, under pressure would drive the HTID of 1,3-PDO into a different chemical scenario: access to the C6 aldehydes chemistry would be provided, with 2 being consumed to produce 3 and $4^{40}$

35 M. Grilc, B. Likozar, J. Levec, Catal. Today 256 (2015) 302.

36 M. Grilc, B. Likozar, J. Levec, Appl. Catal., B 150-151 (2014) 275.

37 M. Grilc, B. Likozar, J. Levec, Biomass Bioenergy 63 (2014) 300.

38 M. Grilc, G. Veryasov, B. Likozar, A. Jesih, J. Levec, Appl. Catal., B 163 (2015) 467.

39 T. Yamada, H. Ono, J. Wood Sci. 47 (2001) 458.

40 (a) Y. Ma, F. Lorenzini, A.C. Marr (2017) unpublished results; (b) F. Lorenzini, A.C. Marr et al., conference proceedings, ISGC 2017, The International Symposium on Green Chemistry 2017, May 16-19, 2017, La Rochelle, France; (c) Y. Ma, F. Lorenzini, A.C. Marr et al., conference proceedings, 9th International Conference on Environmental Catalysis 2016, July 10-13, 2016, Newcastle, New South Wales, Australia; (d) F. Lorenzini, A.C. Marr et al., conference proceedings, CSC 2016 Conference and Exhibition, June 5-9, 2016, 


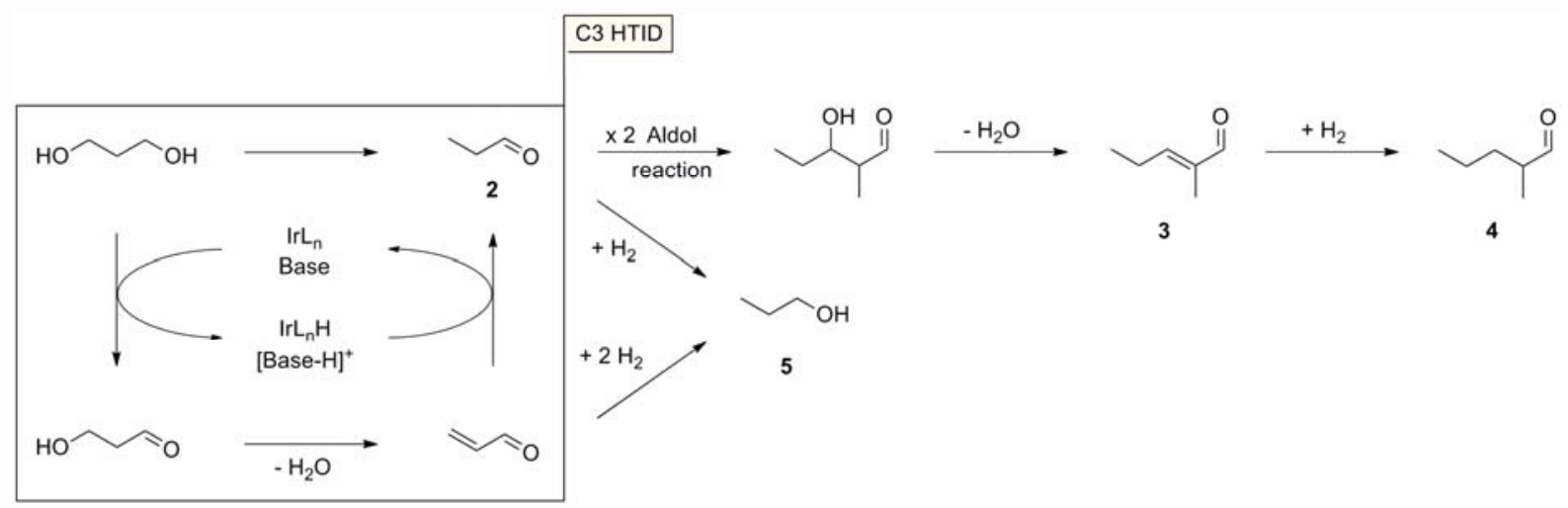

Scheme 3. Postulated reaction mechanism for C3 and C6 aldehydes synthesis from base-assisted HTID of 1,3PDO catalysed by $\mathrm{Cp}^{*} \mathrm{IrX}_{2}(\mathrm{NHC})$ complexes.

The HTID of 1,3-PDO was therefore successfully driven towards the selective production of 2 by reacting 1,3-PDO in the presence of the $\operatorname{Ir}(\mathrm{III})$ complex 1-3F ([1,3PDO]:[Ir] $=74.4-408.2)$ and a base $\left(\mathrm{K}_{2} \mathrm{CO}_{3}\right.$, or $\mathrm{KOH}$, or $\mathrm{CsCO}_{3}$; [Base]:[1,3-PDO] $=$ $0.0229-0.0461$ ), in the ionic liquids EmmimNTf 2, or $\mathrm{N}_{1,8,8,8} \mathrm{NTf}_{2}$, at temperatures varying in the range $100-180{ }^{\circ} \mathrm{C}$, and at a dynamic vacuum of $c a .0 .35$ bar (see tables 1 and $\mathrm{S} 1,2$ and S9, S2 and S31, S3 and S32, S4 and S33, S5 and S34, S6 and S35, S7 and S36, S10 and S37). Both ${ }^{1} \mathrm{H}$ NMR and GC/MS spectra of the isolated, crude product of HTID of 1,3-PDO run in the presence of complex 1-3F, at the above conditions, show that $\mathbf{2}$ is the largely dominant species ( ${ }^{1} \mathrm{H}$ NMR: triplet at $\delta_{\mathrm{H}} 9.78, \mathrm{C}(\mathrm{O}) \mathrm{H}$; GC: $\left.1.7 \mathrm{~min}\right)$. The ${ }^{1} \mathrm{H}$ NMR spectra also display, in the aldehydic region, the resonances due to the small or trace amount of by-products: the small intensity singlet at $\delta_{\mathrm{H}} 9.38$ corresponding to 3 (GC: $6.7,9.1 \mathrm{~min}$ ), the doublet at $\delta_{\mathrm{H}} 9.60$ due to very minor amounts of $\mathbf{4}$ (GC: $4.7,8.6 \mathrm{~min}$ ), and, at higher fields, a triplet of small intensity at $\delta_{\mathrm{H}} 3.59$ due to the $\mathrm{CH}_{2} \mathrm{OH}$ protons of 5 (GC: $2.0 \mathrm{~min}$ ).

To the best of our knowledge, the selective, homogeneous transformation of 1,3-PDO into 2 was only reported in 2016, by this group, using the non-fluorinated version of the $\mathrm{Cp}^{*} \operatorname{IrX}_{2}(\mathrm{NHC})$ complex $\mathbf{1 - 3 F}$, namely $\mathbf{1 - 5 H}$, as the catalyst precursor for HTID. ${ }^{14}$

HTID yields and selectivities were observed to depend on the $\mathrm{Cp}^{*} \operatorname{IrCl}_{2}(\mathrm{NHC})$ precatalyst loading, the nature and loading of the base, the ionic liquid used as the solvent, and the reaction temperature. The influence of each of these factors on the selectivity towards the

Halifax, NS, Canada; (e) F. Lorenzini, A.C. Marr et al., conference proceedings, UKCC 2016, Loughborough, England, UK, January 6-8, 2016; (f) F. Lorenzini, A.C. Marr et al., conference proceedings, 2nd EuGSC, 2nd EuCheMS Congress on Green and Sustainable Chemistry, Lisbon, Portugal, October 4-7, 2015. 
C3 aldehyde 2, the C6 aldehydes 3 and 4, and the alcohol 5, and total yields of 2-5 was then investigated (see Table 1). 
Table 1. HTID of 1,3-PDO in the presence of 1-3F and a base, in ionic liquids: total yields of 2-5, selectivity towards 2, 3, 4, and 5, and TOF.

\begin{tabular}{|c|c|c|c|c|c|c|c|c|c|c|c|c|}
\hline Entry & Solvent & Catalyst & [1,3-PDO]:[Ir] & Base & [Base]:[1,3-PDO] & $\mathrm{T}$ & $\%$ Yield $(2-5)^{a}$ & 2 & 3 & 4 & 5 & $\operatorname{TOF}^{\mathrm{b}}\left[\mathrm{s}^{-1}\right]\left(\times 10^{3}\right)$ \\
\hline 1 & $\mathrm{~N}_{1,8,8,8} \mathrm{NTf}_{2}$ & $1-3 \mathrm{~F}$ & 210.5 & $\mathrm{~K}_{2} \mathrm{CO}_{3}$ & 0.0304 & 150 & 18 & 74.2 & 9.0 & 3.8 & 13.1 & 1.72 \\
\hline 2 & $\mathrm{~N}_{1,8,8,8} \mathrm{NTf}_{2}$ & $1-3 \mathrm{~F}$ & 99.5 & $\mathrm{~K}_{2} \mathrm{CO}_{3}$ & 0.0305 & 150 & 50 & 85.4 & 2.9 & 1.4 & 10.2 & 2.29 \\
\hline 3 & $\mathrm{~N}_{1,8,8,8} \mathrm{NTf}_{2}$ & $1-3 F$ & 76.7 & $\mathrm{~K}_{2} \mathrm{CO}_{3}$ & 0.0317 & 150 & 64 & 72.8 & 12.5 & 0.0 & 14.7 & 2.26 \\
\hline 4 & $\mathrm{~N}_{1,8,8,8} \mathrm{NTf}_{2}$ & $1-3 F$ & 408.2 & $\mathrm{~K}_{2} \mathrm{CO}_{3}$ & 0.0309 & 120 & 1 & 30.2 & 2.6 & 0.0 & 67.1 & 0.18 \\
\hline 5 & $\mathrm{~N}_{1,8,8,8} \mathrm{NTf}_{2}$ & $1-3 F$ & 76.8 & $\mathrm{~K}_{2} \mathrm{CO}_{3}$ & 0.0309 & 120 & 19 & 73.7 & 8.9 & 2.5 & 14.9 & 0.68 \\
\hline 6 & $\mathrm{~N}_{1,8,8,8} \mathrm{NTf}_{2}$ & $1-3 F$ & 77.0 & $\mathrm{~K}_{2} \mathrm{CO}_{3}$ & 0.0303 & 100 & 1 & 71.8 & 28.2 & 0.0 & 0.0 & 0.05 \\
\hline 7 & $\mathrm{~N}_{1,8,8,8} \mathrm{NTf}_{2}$ & $1-3 F$ & 210.7 & $\mathrm{~K}_{2} \mathrm{CO}_{3}$ & 0.0306 & 100 & $<0.5$ & 1 & 1 & 1 & 1 & 1 \\
\hline 8 & $\mathrm{~N}_{1,8,8,8} \mathrm{NTf}_{2}$ & $1-3 F$ & 77.7 & $\mathrm{KOH}$ & 0.0276 & 150 & 42 & 88.8 & 1.5 & 0.0 & 9.7 & 1.52 \\
\hline 9 & $\mathrm{~N}_{1,8,8,8} \mathrm{NTf}_{2}$ & $1-3 F$ & 211.7 & $\mathrm{KOH}$ & 0.0254 & 150 & 50 & 82.1 & 8.5 & 0.0 & 9.4 & 4.94 \\
\hline 10 & $\mathrm{~N}_{1,8,8,8} \mathrm{NTf}_{2}$ & $1-3 F$ & 211.1 & $\mathrm{KOH}$ & 0.0256 & 120 & 5 & 82.8 & 4.3 & 1.4 & 11.6 & 0.48 \\
\hline 11 & $\mathrm{~N}_{1,8,8,8} \mathrm{NTf}_{2}$ & $1-3 F$ & 76.7 & $\mathrm{KOH}$ & 0.0270 & 120 & 23 & 84.7 & 2.9 & 1.4 & 11.0 & 0.83 \\
\hline 12 & $\mathrm{~N}_{1,8,8,8} \mathrm{NTf}_{2}$ & $1-3 F$ & 77.2 & $\mathrm{KOH}$ & 0.0271 & 100 & 1 & 53.4 & 4.6 & 0.9 & 41.1 & 0.05 \\
\hline 13 & $\mathrm{~N}_{1,8,8,8} \mathrm{NTf}_{2}$ & $1-3 F$ & 210.8 & $\mathrm{KOH}$ & 0.0273 & 100 & $<0.5$ & 1 & 1 & 1 & 1 & 1 \\
\hline 14 & $\mathrm{~N}_{1,8,8,8} \mathrm{NTf}_{2}$ & $1-3 F$ & 208.8 & $\mathrm{CsCO}_{3}$ & 0.0309 & 150 & 31 & 80.7 & 4.2 & 1.4 & 13.8 & 3.04 \\
\hline 15 & $\mathrm{~N}_{1,8,8,8} \mathrm{NTf}_{2}$ & $1-3 F$ & 206.2 & $\mathrm{~K}_{2} \mathrm{CO}_{3}$ & 0.0309 & 180 & 39 & 90.8 & 3.1 & 0.0 & 6.1 & 3.76 \\
\hline 16 & EmmimNTf $_{2}$ & $1-3 F$ & 211.3 & $\mathrm{~K}_{2} \mathrm{CO}_{3}$ & 0.0309 & 180 & 100 & 87.1 & 3.0 & 0.0 & 9.9 & 9.76 \\
\hline 17 & EmmimNTf $_{2}$ & $1-3 F$ & 212.4 & $\mathrm{~K}_{2} \mathrm{CO}_{3}$ & 0.0311 & 150 & 70 & 72.7 & 8.8 & 1.2 & 17.3 & 6.86 \\
\hline 18 & EmmimNTf $_{2}$ & $1-3 F$ & 212.6 & $\mathrm{~K}_{2} \mathrm{CO}_{3}$ & 0.0309 & 120 & 24 & 72.7 & 8.8 & 6.1 & 12.4 & 2.37 \\
\hline 19 & EmmimNTf $_{2}$ & $1-3 F$ & 211.4 & $\mathrm{~K}_{2} \mathrm{CO}_{3}$ & 0.0303 & 100 & 7 & 29.4 & 47.2 & 13.4 & 9.9 & 0.65 \\
\hline 20 & EmmimNTf $_{2}$ & $1-3 F$ & 399.6 & $\mathrm{~K}_{2} \mathrm{CO}_{3}$ & 0.0307 & 150 & 18 & 49.1 & 16.9 & 2.5 & 31.5 & 3.35 \\
\hline 21 & EmmimNTf $_{2}$ & $1-3 F$ & 96.6 & $\mathrm{~K}_{2} \mathrm{CO}_{3}$ & 0.0309 & 150 & 81 & 68.4 & 9.4 & 2.3 & 19.8 & 3.62 \\
\hline 22 & EmmimNTf $_{2}$ & $1-3 F$ & 403.9 & $\mathrm{~K}_{2} \mathrm{CO}_{3}$ & 0.0311 & 120 & 6 & 49.0 & 18.6 & 9.9 & 22.5 & 1.05 \\
\hline 23 & EmmimNTf $_{2}$ & $1-3 F$ & 210.9 & $\mathrm{~K}_{2} \mathrm{CO}_{3}$ & 0.0310 & 180 & 41 & 84.1 & 7.2 & 0.0 & 8.7 & 3.98 \\
\hline 24 & EmmimNTf $_{2}$ & $1-3 F$ & 77.1 & $\mathrm{~K}_{2} \mathrm{CO}_{3}$ & 0.0309 & 180 & 63 & 84.1 & 7.2 & 0.0 & 8.7 & 2.26 \\
\hline 25 & EmmimNTf $_{2}$ & $1-3 F$ & 80.3 & $\mathrm{~K}_{2} \mathrm{CO}_{3}$ & 0.0309 & 150 & 85 & 83.6 & 4.3 & 0.0 & 12.1 & 3.17 \\
\hline 26 & EmmimNTf $_{2}$ & $1-3 F$ & 76.7 & $\mathrm{~K}_{2} \mathrm{CO}_{3}$ & 0.0305 & 120 & 53 & 73.6 & 6.3 & 7.5 & 12.6 & 1.89 \\
\hline 27 & EmmimNTf $_{2}$ & $1-3 F$ & 76.7 & $\mathrm{~K}_{2} \mathrm{CO}_{3}$ & 0.0312 & 100 & 20 & 75.1 & 3.9 & 14.0 & 7.0 & 0.72 \\
\hline 28 & EmmimNTf $_{2}$ & $1-3 F$ & 77.1 & $\mathrm{KOH}$ & 0.0283 & 180 & 24 & 89.2 & 1.5 & 0.0 & 9.2 & 0.86 \\
\hline 29 & EmmimNTf $_{2}$ & $1-3 F$ & 207.2 & $\mathrm{KOH}$ & 0.0280 & 180 & 85 & 86.3 & 3.0 & 0.0 & 10.7 & 8.19 \\
\hline 30 & EmmimNTf $_{2}$ & $1-3 F$ & 212.8 & $\mathrm{KOH}$ & 0.0461 & 150 & 20 & 73.8 & 10.2 & 0.0 & 16.0 & 1.93 \\
\hline 31 & EmmimNTf $_{2}$ & $1-3 F$ & 77.8 & $\mathrm{KOH}$ & 0.0283 & 150 & 79 & 87.6 & 1.5 & 0.0 & 10.9 & 2.83 \\
\hline 32 & EmmimNTf $_{2}$ & $1-3 F$ & 102.1 & $\mathrm{KOH}$ & 0.0229 & 150 & 38 & 78.5 & 0.0 & 0.0 & 21.5 & 1.78 \\
\hline 33 & EmmimNTf $_{2}$ & $1-3 F$ & 208.8 & $\mathrm{KOH}$ & 0.0275 & 150 & 85 & 88.8 & 1.5 & 0.0 & 9.7 & 8.18 \\
\hline 34 & EmmimNTf $_{2}$ & $1-3 F$ & 395.6 & $\mathrm{KOH}$ & 0.0275 & 150 & 44 & 85.4 & 2.9 & 1.4 & 10.2 & 8.02 \\
\hline 35 & EmmimNTf $_{2}$ & $1-3 F$ & 76.4 & $\mathrm{KOH}$ & 0.0272 & 120 & 33 & 79.6 & 2.7 & 4.0 & 13.6 & 1.18 \\
\hline 36 & EmmimNTf $_{2}$ & $1-3 F$ & 207.9 & $\mathrm{KOH}$ & 0.0259 & 120 & 37 & 77.5 & 5.3 & 3.9 & 13.2 & 3.54 \\
\hline 37 & EmmimNTf $_{2}$ & $1-3 F$ & 212.1 & $\mathrm{CsCO}_{3}$ & 0.0305 & 150 & 58 & 86.3 & 3.0 & 0.0 & 10.7 & 5.71 \\
\hline 38 & $\mathrm{~N}_{1,8,8,8} \mathrm{NTf}_{2}$ & No catalyst & 1 & $\mathrm{~K}_{2} \mathrm{CO}_{3}$ & 0.0312 & 150 & $<0.5$ & 1 & 1 & 1 & 1 & 1 \\
\hline 39 & EmmimNTf $_{2}$ & $1-3 \mathrm{~F}$ & 213.2 & No base & / & 150 & $<0.5$ & i & 1 & I & 1 & i \\
\hline
\end{tabular}

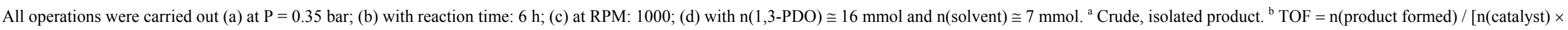
time]. 
The pre-catalyst $\mathrm{Cp}^{*} \operatorname{IrX}_{2}(\mathrm{NHC})$ complex 1-3F, and the base, are indispensable for the HTID of 1,3-PDO to occur. 1,3-PDO remains unreacted in the absence of 1-3F (in Table 1, see entry 38). When the HTID is carried out in the presence of 1-3F, but in the absence of base, no reaction of 1,3-PDO is observed (in Table 1, see entry 39).

The effect of different bases, assisting the HTID of 1,3-PDO, on the total yields of 2-5 and selectivity towards $2,3,4$, and 5 was then investigated. In the range of temperatures 100 $-150{ }^{\circ} \mathrm{C}, \mathrm{K}_{2} \mathrm{CO}_{3}$ and $\mathrm{KOH}$ allowed the highest total yields of 2-5 (85 and 89\%, respectively) and selectivities towards 2 ( $85 \%$, for both of them) as compared to $\mathrm{CsCO}_{3}$. In general, $\mathrm{KOH}$ allowed a better catalytic performance than $\mathrm{K}_{2} \mathrm{CO}_{3}$ and $\mathrm{CsCO}_{3}$. For example, when running the HTID of 1,3-PDO at $150{ }^{\circ} \mathrm{C}$, at [1,3-PDO]:[Ir] $\cong 210.0$, in $\mathrm{EmmimNTf}_{2}$, the total yield of 2-5 was found to be $85 \%$ in the presence of $\mathrm{KOH}$ (in Table 1, see entry 33), and 70 and $58 \%$ in the presence of $\mathrm{K}_{2} \mathrm{CO}_{3}$ (in Table 1, see entry 17) and $\mathrm{CsCO}_{3}$ (in Table 1, see entry 37), respectively. The selectivity towards 2 was high in the presence of any of the bases tested: 89 , 73 and $86 \%$ in the presence of $\mathrm{KOH}, \mathrm{K}_{2} \mathrm{CO}_{3}$ and $\mathrm{CsCO}_{3}$, respectively. Small, traces, or no measurable amount of the $\mathrm{C} 6$ aldehydes $3\left(2,9\right.$, and $3 \%$ in the presence of $\mathrm{KOH}, \mathrm{K}_{2} \mathrm{CO}_{3}$ and $\mathrm{CsCO}_{3}$, respectively), and $4\left(0,1\right.$, and $0 \%$ in the presence of $\mathrm{KOH}, \mathrm{K}_{2} \mathrm{CO}_{3}$ and $\mathrm{CsCO}_{3}$, respectively) were detected using any of the above bases. 10, 17, and $11 \%$ of 5 was observed to have formed in the presence of $\mathrm{KOH}, \mathrm{K}_{2} \mathrm{CO}_{3}$ and $\mathrm{CsCO}_{3}$, respectively.

A similar trend was observed when running the HTID of 1,3-PDO still at $150{ }^{\circ} \mathrm{C}$ and at [1,3-PDO]:[Ir] $\cong 210.0$, but in $\mathrm{N}_{1,8,8,8} \mathrm{NTf}_{2}$. High selectivities towards the $\mathrm{C} 3$ aldehyde 2 were observed when using $\mathrm{KOH}(82 \%), \mathrm{K}_{2} \mathrm{CO}_{3}(74 \%)$, and $\mathrm{CsCO}_{3}(81 \%)$ (in Table 1, see entries 9,1 , and 14, respectively). The highest total yields of 2-5 were still observed in the presence of $\mathrm{KOH}$, as compared to $\mathrm{K}_{2} \mathrm{CO}_{3}$ and $\mathrm{CsCO}_{3}$, although they were much lower than those observed in EmmimNTf $2: 50$ vs. 85 \%, 18 vs. 70 \%, and 31 vs. 58 \%, in the presence of $\mathrm{KOH}$, $\mathrm{K}_{2} \mathrm{CO}_{3}$ and $\mathrm{CsCO}_{3}$, respectively.

The high yields and selectivity towards 2 that were achievable when using both $\mathrm{KOH}$ and $\mathrm{K}_{2} \mathrm{CO}_{3}$, prompted us to select $\mathrm{K}_{2} \mathrm{CO}_{3}$ as the preferable assisting base for the HTID of 1,3PDO. Previous and current studies conducted by this group ${ }^{14,40}$ on the selective production of C3 and C6 aldehydes using base-assisted HTID of 1,3-PDO using Ir(III) complex $\mathrm{Cp}^{*} \operatorname{IrX}_{2}(\mathrm{NHC})$ as the catalyst precursors, have shown that yields and selectivities are affected by the base molar concentration, and have led to the conclusion that the optimal ratio $\left[\mathrm{K}_{2} \mathrm{CO}_{3}\right]:[1,3-\mathrm{PDO}]$ to be used for the selective production of $\mathbf{2}$, with high total yields of 2-5, is $\left[\mathrm{K}_{2} \mathrm{CO}_{3}\right]:[1,3-\mathrm{PDO}] \cong 0.031$. Higher and lower base concentrations would result in lower yields, and lower selectivities. We speculate that the higher base concentration may stimulate 
side-reactions, including dehydrogenation, retro-aldol condensation, catalyst deactivation, and orthometallation ${ }^{32 \mathrm{~d}}$ of the $\mathrm{Cp}^{*} \operatorname{IrX}_{2}(\mathrm{NHC})$ complex.

The effect of the two ionic liquids, as the solvent media, on the total yields of 2-5 and selectivity towards 2, 3, 4, and 5 was further investigated. The better performance of the HTID of 1,3-PDO towards the selective production of 2 in EmmimNTf $f_{2}$, compared to $\mathrm{N}_{1,8,8,8} \mathrm{NTf}_{2}$, was confirmed under further reaction conditions. For example, when running the HTID of 1,3-PDO at [1,3-PDO]:[Ir] $\cong 77$, using $\mathrm{K}_{2} \mathrm{CO}_{3}$, the total yields of $\mathbf{2 - 5}$ were found to be much higher in EmmimNTf $f_{2}$ than in $\mathrm{N}_{1,8,8,8} \mathrm{NTf}_{2}$, at any reaction temperature (85 vs. $64 \%$ at $150{ }^{\circ} \mathrm{C}$ - in Table 1 , see entries 25 and 3, respectively; 53 vs. $19 \%$ at $120{ }^{\circ} \mathrm{C}$ - see entries 26 and 5, respectively). However, the selectivity towards 2 remained high in both EmmimNTf ${ }_{2}$ and $\mathrm{N}_{1,8,8,8} \mathrm{NTf}_{2}$, namely 84 and $73 \%$, respectively, at $150{ }^{\circ} \mathrm{C}$, and $74 \%$, in both of them, at $120{ }^{\circ} \mathrm{C}$. Small, traces or no measurable amount of 3 (4 and $6 \%$, at 150 and $120{ }^{\circ} \mathrm{C}$, respectively, in EmmimNTf $; 13$ and $9 \%$, at 150 and $120{ }^{\circ} \mathrm{C}$, respectively, in $\left.\mathrm{N}_{1,8,8,8} \mathrm{NTf}_{2}\right), 4\left(0\right.$ and $8 \%$, at 150 and $120{ }^{\circ} \mathrm{C}$, respectively, in EmmimNTf ${ }_{2} ; 0$ and $3 \%$, at 150 and $120{ }^{\circ} \mathrm{C}$, respectively, in $\left.\mathrm{N}_{1,8,8,8} \mathrm{NTf}_{2}\right)$ and $5\left(12\right.$ and $13 \%$, at 150 and $120{ }^{\circ} \mathrm{C}$, respectively, in EmmimNTf $; 15 \%$ at both $150{ }^{\circ} \mathrm{C}$ and $120{ }^{\circ} \mathrm{C}$, in $\mathrm{N}_{1,8,8,8} \mathrm{NTf}_{2}$ ) were detected in both EmmimNTf $f_{2}$ and $\mathrm{N}_{1,8,8,8} \mathrm{NTf}_{2}$. In particular, the use of EmmimNTf $f_{2}$ allowed significant conversions and selectivity towards 2 also at $100{ }^{\circ} \mathrm{C}$, a low temperature for efficient HT reactions to occur: $20 \%$ total yield of 2-5 was observed, with high selectivity towards 2 (75\%) (in Table 1, see entry 27$)$. Only $1 \%$ total yield of 2-5 was instead achieved in $\mathrm{N}_{1,8,8,8} \mathrm{NTf}_{2}$ at $100{ }^{\circ} \mathrm{C}$, and, although the selectivity towards 2 was found to be high $(72 \%)$ (in Table 1, see entry 6), a high amount of the unsaturated C6 aldehyde 3 was detected in the isolated crude product ( $28 \%$, vs. $4 \%$ in EmmimNTf $_{2}$ ).

A similar trend was observed when using $\mathrm{KOH}$, instead, as the assisting base. For example, when running the HTID of 1,3-PDO at [1,3-PDO]:[Ir] $\cong 77$, while high selectivity towards 2 was detected in both EmmimNTf $f_{2}$ and $\mathrm{N}_{1,8,8,8} \mathrm{NTf}_{2}\left(88\right.$ and $89 \%$ at $150{ }^{\circ} \mathrm{C}$-in Table 1, see entries 31 and 8-, respectively, and 80 and $85 \%$ at $120{ }^{\circ} \mathrm{C}$-in Table 1 , see entries 35 and 11-, respectively), higher total yields of 2-5 were observed in EmmimNTf $_{2}$ compared to $\mathrm{N}_{1,8,8,8} \mathrm{NTf}_{2}: 79$ vs. $42 \%$ at $150{ }^{\circ} \mathrm{C}$, and 33 vs. $23 \%$ at $120{ }^{\circ} \mathrm{C}$.

The different HTID performance observed in the two solvent media, EmmimNTf $\mathrm{N}_{2}$ and $\mathrm{N}_{1,8,8,8} \mathrm{NTf}_{2}$, must be due to some chemical influence of the ionic liquid in the reaction mechanism. ${ }^{9}$ Both the ionic liquids have been found to be stable throughout the HTID. The ${ }^{1} \mathrm{H}$ NMR spectra of the reacting mixtures show that no decomposition of the ionic liquids occurs during the course of the reaction. The triplet at $\delta_{\mathrm{H}} 0.86$ due to the $-\mathrm{CH}_{2} \mathrm{CH}_{3}$ methylic 
protons, the singlet at 2.92 due to the $-\mathrm{NCH}_{3}$ methylic protons, and the multiplet at $\delta_{\mathrm{H}} 3.18$ due to the $-\mathrm{NCH}_{2}-$ methylenic protons of $\mathrm{N}_{1,8,8,8} \mathrm{NTf}_{2}$ remain unchanged throughout the reaction time. The resonances due to the protons of $\mathrm{EmmimNTf}_{2}$, namely the triplet at $\delta_{\mathrm{H}}$ 1.51 due to the $-\mathrm{CH}_{2} \mathrm{CH}_{3}$ methylic protons, the quartet at $\delta_{\mathrm{H}} 4.14$ due to the $-\mathrm{CH}_{2} \mathrm{CH}_{3}$ methylenic protons, and the two doublets at $\delta_{\mathrm{H}} 7.62$ and 7.63 due to the two $\mathrm{HC}=\mathrm{CH}$ imidazolic protons also remain unchanged.

The effect of the pre-catalyst loading on the total yields of 2-5 and selectivity towards 2, 3, 4, and 5 was investigated. Increasing the pre-catalyst loading was found to enhance the catalytic performance when using $\mathrm{K}_{2} \mathrm{CO}_{3}$ as the assisting base. For example, when running the HTID of $1,3-\mathrm{PDO}$ at $150{ }^{\circ} \mathrm{C}$, at $\left[\mathrm{K}_{2} \mathrm{CO}_{3}\right]:[1,3-\mathrm{PDO}] \cong 0.031$, in $\mathrm{N}_{1,8,8,8} \mathrm{NTf}_{2}$, the total yields of 2-5 were found to increase from 18, to 50 , to $64 \%$, when increasing the pre-catalyst loading from $[1,3-\mathrm{PDO}]:[\mathrm{Ir}] \cong 210.0$, to $c a$. 100.0 , to $c a$. 75.0 . However, at any ratio [1,3PDO]:[Ir], high selectivities towards 2 were observed: $74 \%$ at $[1,3-\mathrm{PDO}]:[\mathrm{Ir}] \cong 210.0,85 \%$ at $[1,3-\mathrm{PDO}]:[\mathrm{Ir}] \cong 100.0$, and $73 \%$ at $[1,3-\mathrm{PDO}]:[\mathrm{Ir}] \cong 75.0$ (in Table 1 , see entries 1-3). Selectivities towards the C6 aldehydes 3 and 4 (3: $3-13 \% ; 4: 0-4 \%)$ and $5(10-15 \%)$ remained low at any ratio [1,3-PDO]:[Ir]. An analogous trend was observed in EmmimNTf at the same reaction conditions. High or very high selectivities towards 2 were observed at [1,3-PDO]:[Ir] $\geq 210.0$. Increasing the pre-catalyst loading from [1,3-PDO]:[Ir] $\cong 400.0$, to ca. 210.0, to ca. 100.0, to $c a$. 75.0 , resulted in enhanced total yields of $2-5$ from 18 , to 70 , to 81 , to $85 \%$ (in Table 1, see entries 20, 17, 21, and 25, respectively). In EmmimNTf 2 , unlike in $\mathrm{N}_{1,8,8,8} \mathrm{NTf}_{2}$, the catalyst loading also affects products selectivities. The selectivity towards the $\mathrm{C} 3$ aldehyde 2 rises from 49 to $84 \%$ when increasing the catalyst loading from [1,3PDO]:[Ir] $\cong 400.0$, to $c a$. 75.0 (selectivity towards 2 was found to be 73 and $68 \%$ at [1,3$\mathrm{PDO}]:[\mathrm{Ir}] \cong 210.0$, and ca. 100.0 , respectively). At [1,3-PDO]:[Ir] $\cong 400.0$, when the selectivity towards 2 is poorer, significant amount of $3(17 \%)$ and $5(32 \%)$, higher than usual, were detected in the isolated crude product.

Catalyst loading was found to have a less significant effect on the performance of 1-3F as the catalyst precursor when running the HTID of 1,3-PDO in the presence of $\mathrm{KOH}$ as the assisting base. For example, when running the HTID of 1,3-PDO at $150^{\circ} \mathrm{C}$, in EmmimNTf the total yield of $2-5$ was found to be 85 and $79 \%$ at [1,3-PDO]:[Ir] $\cong 210.0$, and ca. 75.0, respectively. The selectivity towards 2 was also found to be similar, and remarkably high, namely $89 \%$ at $[1,3-\mathrm{PDO}]:[\mathrm{Ir}] \cong 210.0$, and $88 \%$ at [1,3-PDO]:[Ir] $\cong 75.0$ (in Table 1 , see entries 33 and 31, respectively), with no or trace amounts of C6 aldehydes 3 (2\%) and 4 (0 $\%)$, and small amounts of $5(10-11 \%)$, being formed. At the same conditions, but in 
$\mathrm{N}_{1,8,8,8} \mathrm{NTf}_{2}$, the total yields of 2-5 were again found to be similar, 50 and $42 \%$, at [1,3$\mathrm{PDO}]:[\mathrm{Ir}] \cong 210.0$ and 75.0, respectively, and lower than those found in EmmimNTf $_{2}$ (confirming the above trend regarding the ionic liquid effect). Also in $\mathrm{N}_{1,8,8,8} \mathrm{NTf}_{2}$, the reaction showed to be highly selective towards 2 at any ratio [1,3-PDO]:[Ir] ( [1,3-PDO]:[Ir] $\cong 210.0: 82 \%$; [1,3-PDO]:[Ir] $\cong 75.0: 89 \%$ ) (in Table 1, see entries 9 and 8, respectively); only small amounts of $\mathbf{3}, \mathbf{4}$, and 5 were observed to be formed $(0-10 \%)$. However, when lowering the temperature to $120^{\circ} \mathrm{C}$, while still only little changes are observed with regards to both total yields of $2-5$ (37\% at [1,3-PDO]:[Ir] $\cong 210.0$, and $33 \%$ at [1,3-PDO]:[Ir] $\cong$ $75.0)$ and selectivity towards 2 (78 \% at [1,3-PDO]:[Ir] $\cong 210.0$, and $80 \%$ at [1,3-PDO]:[Ir] $\cong$

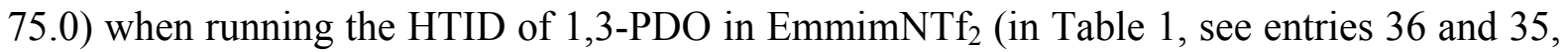
respectively), significant total yield of 2-5 was instead observed in $\mathrm{N}_{1,8,8,8} \mathrm{NTf}_{2}$ only at [1,3PDO]:[Ir] $\cong 75.0$ (23\%; selectivity towards 2: $85 \%$ ) (in Table 1, see entry 11); at lower catalyst loading ([1,3-PDO]:[Ir] $\cong 210.0)$, only $5 \%$ total yield of $\mathbf{2 - 5}$ (selectivity towards $\mathbf{2}$ : $83 \%$ ) was obtained (in Table 1, see entry 10).

The effect of the temperature on the reaction yields and selectivity was then investigated. Significant production of 2 at $100{ }^{\circ} \mathrm{C}$ was observed only in EmmimNTf 2 , at [1,3-PDO]:[Ir] $\cong 75.0$, using $\mathrm{K}_{2} \mathrm{CO}_{3}$ as the assisting base: $20 \%$ total yield of $2-5$ was obtained, with $75 \%$ selectivity towards 2 (in Table 1, see entry 27). Little traces of, or no crude was obtained when running the HTID of 1,3-PDO at $100{ }^{\circ} \mathrm{C}$, at any other reaction conditions (in Table 1, see entries 6, 7, 12, 13, and 19). In general, increasing the temperature to $120{ }^{\circ} \mathrm{C}$ and $150{ }^{\circ} \mathrm{C}$ resulted in significant enhancements in the reaction yield, reaching maximum total yields of $2-5$ of $85 \%$ at $150{ }^{\circ} \mathrm{C}$ (in Table 1, see entries 25 and 33). Small rises in selectivity towards 2 were observed correspondingly. For example, when running the HTID of 1,3-PDO in $\mathrm{N}_{1,8,8,8} \mathrm{NTf}_{2}$, at $[1,3-\mathrm{PDO}]:[\mathrm{Ir}] \cong 75.0$, and $\left[\mathrm{K}_{2} \mathrm{CO}_{3}\right]$ :[1,3-PDO] $\cong 0.031$, the total yield of 2-5 rose from 1 to 19 to $64 \%$ when increasing the temperature from $100{ }^{\circ} \mathrm{C}$, to $120^{\circ} \mathrm{C}$, to $150{ }^{\circ} \mathrm{C}$, respectively. Correspondingly, the selectivity towards 2 remained high and changed little $(72,74$, and $73 \%$, respectively) (in Table 1, see entries 6, 5 and 3, respectively). The total yield of 2-5 rose from 20 to 53 , to $85 \%$ when the temperature was increased from $100{ }^{\circ} \mathrm{C}$, to $120{ }^{\circ} \mathrm{C}$, to $150{ }^{\circ} \mathrm{C}$, respectively, running the HTID of 1,3-PDO under the same conditions, but in $\operatorname{EmmimNTf}_{2}$, and the selectivity towards 2 was little affected (75, 74, $84 \%$, respectively) (in Table 1, see entries 27, 26 and 25, respectively).

Increasing the temperature to $180^{\circ} \mathrm{C}$ allowed quantitative total yields of $\mathbf{2 - 5}$, with high selectivity towards the $\mathrm{C} 3$ aldehyde ( $87 \%$ ), when running the HTID of 1,3-PDO in EmmimNTf 2 , at $[1,3-\mathrm{PDO}]:[\mathrm{Ir}] \cong 210.0$, and $\left[\mathrm{K}_{2} \mathrm{CO}_{3}\right]:[1,3-\mathrm{PDO}] \cong 0.031$ (in Table 1, see 
entry 16). At other reaction conditions, increasing the temperature from $150{ }^{\circ} \mathrm{C}$ to $180{ }^{\circ} \mathrm{C}$ resulted in little or detrimental effect on the total yields of 2-5.

The HTID of 1,3-PDO to 2 in the presence of 1-3F was proven to be homogeneous via mercury poisoning experiments: ${ }^{32 a}$ the catalytic activity of $1-3 \mathbf{F}$ remained essentially unchanged in the presence of mercury (see Table 2).

Furthermore, the catalytic system is not sensitive to air and tolerated the presence of water. Highly selective production of $2(86 \%)$ was observed when running the HTID of 1,3PDO in EmmimNTf $f_{2}$, in the presence of 1-3F and $\mathrm{K}_{2} \mathrm{CO}_{3}$, and a significant amount of water. 


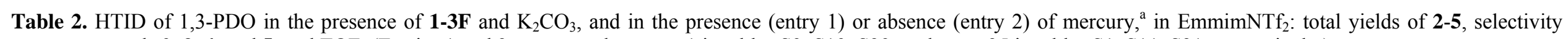
towards 2, 3, 4, and 5, and TOF. (Entries 1 and 2 correspond to entry 1 in tables S9, S19, S29, and entry 25 in tables S1, S11, S21, respectively.)

\begin{tabular}{|c|c|c|c|c|c|c|c|c|c|c|c|c|}
\hline Entry & Solvent & Catalyst & [1,3-PDO]:[Ir] & Base & [Base]:[1,3-PDO] & $\mathrm{T}$ & $\%$ Yield $(2-5)^{\mathrm{b}}$ & 2 & 3 & 4 & 5 & $\operatorname{TOF}^{\mathrm{c}}\left[\mathrm{s}^{-1}\right]\left(\times 10^{3}\right)$ \\
\hline 1 & EmmimNTf $_{2}$ & $1-3 F$ & 77.7 & $\mathrm{~K}_{2} \mathrm{CO}_{3}$ & 0.0308 & 150 & 86 & 73.0 & 8.8 & 0.0 & 18.1 & 3.08 \\
\hline 2 & EmmimNTf $_{2}$ & $1-3 F$ & 80.3 & $\mathrm{~K}_{2} \mathrm{CO}_{3}$ & 0.0309 & 150 & 85 & 83.6 & 4.3 & 0.0 & 12.1 & 3.17 \\
\hline
\end{tabular}

All operations were carried out (a) at $\mathrm{P}=0.35$ bar; (b) with reaction time: $6 \mathrm{~h}$; (c) at RPM: 1000 ; (d) with $\mathrm{n}(1,3-\mathrm{PDO}) \cong 16 \mathrm{mmol}$ and $\mathrm{n}\left(\right.$ solvent) $\cong 7$ mmol. ${ }^{\mathrm{a}}$ Amount of mercury added: 3 drops. ${ }^{\mathrm{b}}$ Crude, isolated product. ${ }^{\mathrm{c}}$ $\mathrm{TOF}=\mathrm{n}($ product formed $) /[\mathrm{n}($ catalyst $) \times$ time $]$ 


\section{Recycling catalyst precursor 1-3F.}

The evidence collected screening the effect of the reaction conditions on the yields of, and selectivity towards, the $\mathrm{C} 3$ aldehyde 2 prompted us to investigate the recyclability of the 1-3F catalyst precursor running the HTID of 1,3-PDO in EmmimNTf ${ }_{2}$, using $\mathrm{K}_{2} \mathrm{CO}_{3}$ as the assisting base, at $\left[\mathrm{K}_{2} \mathrm{CO}_{3}\right]:[1,3-\mathrm{PDO}] \cong 0.031$, at both $[1,3-\mathrm{PDO}]:[\mathrm{Ir}] \cong 210.0$ and ca. 75.0, and at both $120^{\circ} \mathrm{C}$ and $150{ }^{\circ} \mathrm{C}$.

1-3F was found to be a highly recyclable catalyst precursor. The catalytic system generated by $1-3 F$ was found to be recyclable for at least 10 catalytic runs at both $120{ }^{\circ} \mathrm{C}$ and $150{ }^{\circ} \mathrm{C}$, at catalyst loading [1,3-PDO]:[Ir] $\cong 75.0$. Over the 10 recycling runs, no significant loss of activity or selectivity towards 2 was observed. Figure 1 shows duplicates $^{41}$ of the selectivity towards $2,3,4$, and 5 , varying little, over the 10 recycling runs, as observed when recycling 1-3F, at[1,3-PDO]:[Ir] $\cong 75.0$, in EmmimNTf $_{2}$, in the presence of $\mathrm{K}_{2} \mathrm{CO}_{3}$, at 150 ${ }^{\circ} \mathrm{C}$. In Figure 2, triplicates ${ }^{42}$ of the almost identical selectivity towards 2, 3, 4, and 5, and the total yield of 2-5, observed when recycling 1-3F at the same conditions, for the first five recycling runs, are represented. At $150{ }^{\circ} \mathrm{C}$, the selectivity towards 2 remained almost unchanged (for example: $1^{\text {st }}$ catalytic run: $78 \% ; 10^{\text {th }}$ catalytic run: $79 \%$ ) (See Figure S2, and Table S32, and also figures S1 and S3, and tables S31 and S33), while the percentage total yield of 2-5 was $85 \%$ after the $1^{\text {st }}$ catalytic run, and $70 \%$ after the $10^{\text {th }}$ catalytic run, varying overall within the range $61-99 \%$.

41 'Duplicates': yield and selectivity average numbers out of two experiments. 

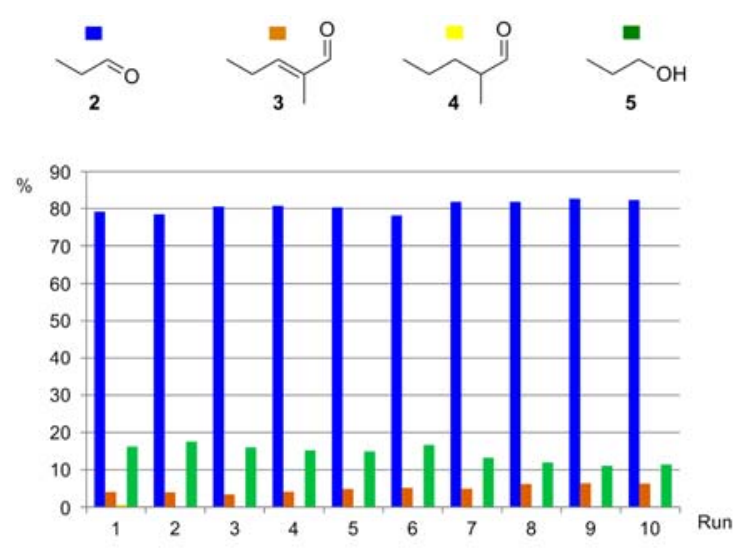

Figure 1. Recycling 1-3F as catalyst precursor towards HTID of 1,3-PDO ([1,3-PDO]:[Ir] $\cong 75.0)$ in EmmimNTf ${ }_{2}$, in the presence of $\mathrm{K}_{2} \mathrm{CO}_{3}$, at $150{ }^{\circ} \mathrm{C}$ and 0.35 bar: selectivity towards 2,3 , 4, and 5 (duplicates).

Yield

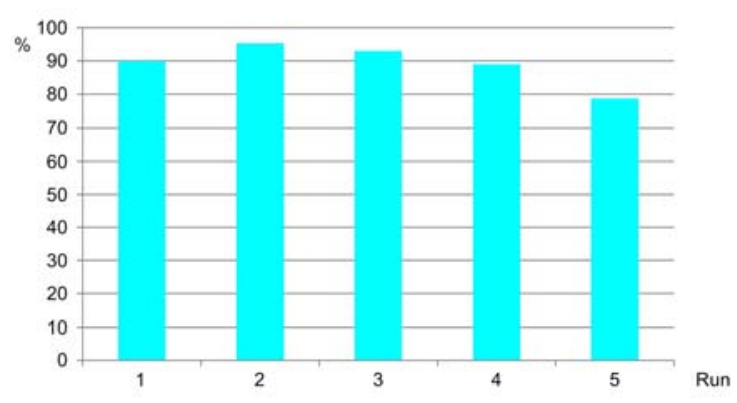

(a)
Selectivity
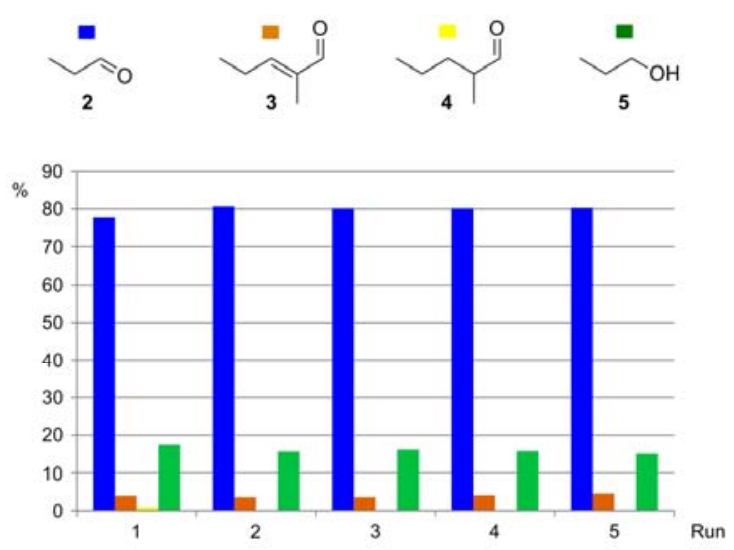

(b)

Figure 2. Recycling 1-3F as catalyst precursor towards HTID of 1,3-PDO ([1,3-PDO]:[Ir] $\cong 75.0)$ in EmmimNTf 2 , in the presence of $\mathrm{K}_{2} \mathrm{CO}_{3}$, at $150{ }^{\circ} \mathrm{C}$ and 0.35 bar: (a) total yield of 2-5 (triplicates); (b) selectivity towards $2,3,4$, and 5 (triplicates).

No significant loss of activity or selectivity towards 2 was observed over 10 recycling runs at $120^{\circ} \mathrm{C}$. Figure 3 shows duplicates, over the first five recycling runs, of the selectivity towards 2, 3, 4, and 5, and total yields of 2-5, varying little, as observed when recycling 1-3F, at $[1,3-\mathrm{PDO}]:[\mathrm{Ir}] \cong 75.0$, in EmmimNTf 2 , in the presence of $\mathrm{K}_{2} \mathrm{CO}_{3}$, at $120{ }^{\circ} \mathrm{C}$. Over the 10 recycling runs, the total yield of 2-5 was $58 \%$ after the $1^{\text {st }}$ catalytic run, and $53 \%$ after the $10^{\text {th }}$ catalytic run, the percentage total yield of 2-5 varying in the range $53-71 \%$ (See Figure S4, and Table S34); the selectivity towards 2 was found to be $82 \%$ in the $1^{\text {st }}$ catalytic run, and $73 \%$ in the $10^{\text {th }}$ catalytic run, varying in the range $70-86 \%$. 
Yield

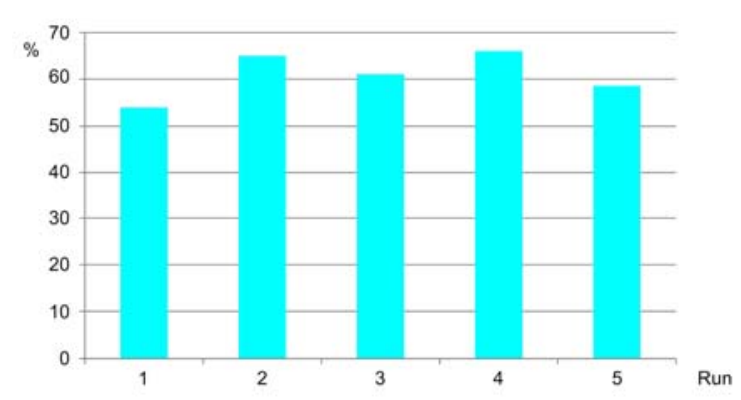

(a)
Selectivity

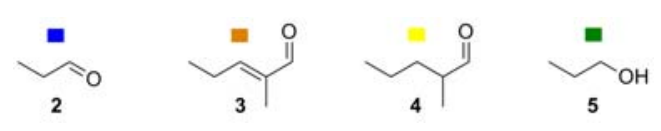

(b)

Figure 3. Recycling 1-3F as catalyst precursor towards HTID of 1,3-PDO ([1,3-PDO]:[Ir] $\cong 75.0)$ in EmmimNTf $f_{2}$, in the presence of $\mathrm{K}_{2} \mathrm{CO}_{3}$, at $120^{\circ} \mathrm{C}$ and 0.35 bar: (a) total yield of 2-5 (duplicates); (b) selectivity towards $\mathbf{2}, \mathbf{3}, \mathbf{4}$, and $\mathbf{5}$ (duplicates).

The catalyst precursor $\mathbf{1 - 3 F}$ was also found to be recyclable at $[1,3-\mathrm{PDO}]:[\mathrm{Ir}] \cong 210.0$, when running the HTID of 1,3-PDO in EmmimNTf $f_{2}$ at $\left[\mathrm{K}_{2} \mathrm{CO}_{3}\right]:[1,3-\mathrm{PDO}] \cong 0.031$, and at $150^{\circ} \mathrm{C}$. The catalyst was found to be recyclable for at least 5 catalytic runs. Also in this case, no significant loss of selectivity towards 2 or activity was observed: the selectivity towards 2 varied in the range $82-85 \%$, while the percentage total yield of 2-5 was found to be $78 \%$ in the $1^{\text {st }}$ catalytic run and $76 \%$ in $5^{\text {th }}$ catalytic run, varying in the range $68-83 \%$ (See Figure S6, and Table S36).

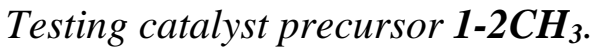

The HTID of 1,3-PDO was then attempted by reacting 1,3-PDO in the presence of the $\mathrm{Ir}(\mathrm{III})$ complex 1-2CH 3 and $\mathrm{K}_{2} \mathrm{CO}_{3}$, at $\left[\mathrm{K}_{2} \mathrm{CO}_{3}\right]:[1,3-\mathrm{PDO}] \cong 0.031$, at [1,3-PDO]:[Ir] $=49.1$ and 99.1, at temperatures $150{ }^{\circ} \mathrm{C}$ and $120{ }^{\circ} \mathrm{C}$, respectively, in EmmimNTf 2 , and at a dynamic vacuum of ca. 0.35 bar. No product formation was observed when testing $\mathbf{1 - 2} \mathbf{C H}_{\mathbf{3}}$ at $[1,3-$ PDO]:[Ir] $=99.1$ and $120{ }^{\circ} \mathrm{C}$, while the reaction of 1,3-PDO in the presence of $\mathbf{1 - 2} \mathbf{C H}_{3}$, at [1,3-PDO]:[Ir] $=49.1$, at $150{ }^{\circ} \mathrm{C}$, produced total yields of $\mathbf{2 - 5} \leq 0.01 \%$ (see Table 3 ). In addition, only trace amounts of product were formed in $\mathrm{N}_{1,8,8,8} \mathrm{NTf}_{2}$ : testing the activity of $\mathbf{1}$ $\mathbf{2} \mathbf{C H}_{3}$ at [1,3-PDO]:[Ir] $=49.0$, at $150{ }^{\circ} \mathrm{C}$, led to $c a .0 .5 \%$ total yield of $\mathbf{2 - 5}$.

Replacement of H or F atoms (as in the HTID-active catalyst precursors 1-5H and 13F) bound to the ortho- $\mathrm{C}$ atoms of the benzyl arm of the carbene ligand with $\mathrm{CH}_{3}$, has 
resulted in the inhibition of the catalytic activity of complexes $\mathrm{Cp}^{*} \mathrm{IrCl}_{2}(\mathrm{NHC})$ towards HTID of 1,3-PDO. The origins of this effect could be steric or electronic as the methyl grouping is the bulkiest and most electron donating group attempted. However the observation may have more profound meaning, as for $\mathrm{C}-\mathrm{H}$ and $\mathrm{C}-\mathrm{F}$ orthometallation is feasible, but the methyl group is unlikely to react with the metal centre. This, coupled to the remarkable activity and selectivity achieved using 1-3F as the catalyst precursor has prompted further, current work in this group aimed at exploring fluorine substitution in the benzyl arm of the carbene ligand of $\mathrm{Cp}^{*} \mathrm{IrCl}_{2}(\mathrm{NHC})$ complexes for HTID of 1,3-PDO. The beneficial or detrimental contribution of cyclometallation to HTID is being investigated. ${ }^{29}$ The possibly crucial role played in cyclometallation reactions of fluorinated $\mathrm{Cp}^{*} \mathrm{IrCl}_{2}(\mathrm{NHC})$ complexes, occuring via regiospecific carbon-fluorine bond activation, by silver particles generated in the synthesis of the $\operatorname{Ir}(\mathrm{NHC})$ complexes by transmetalation of imidazolylidenes from the corresponding silver carbene derivative to $\left[\mathrm{Cp}^{*} \mathrm{IrCl}_{2}\right]_{2}$, is being looked into. ${ }^{29 a}$ Furthermore, the lack of activity of complex 1-2-CH 3 in HTID of 1,3-PDO prevented from any further investigation on the effect of alkyl substitution in the benzyl arm of the Ir(III) complexes carbene ligand; however, the electronic and steric effects of $N$-alkyl substitution on the carbene ligand of catalyst precursors $\mathrm{Cp}^{*} \mathrm{IrCl}_{2}(\mathrm{NHC})$ on HTID of 1,3-PDO for the production of value-added target chemicals is currently being investigated. ${ }^{43}$ Current work is also aimed at exploiting the catalytic activity of precursors $\mathrm{Cp}^{*} \mathrm{IrCl}_{2}(\mathrm{NHC})$ to drive the HTID of 1,3-PDO away from the C3 aldehyde 2 and towards the selective production of other value-added, longer chain, aldehydes. ${ }^{40}$ The postulated reaction mechanism for the base-assisted HTID of 1,3-PDO catalysed by $\mathrm{Cp}^{*} \mathrm{IrX}_{2}(\mathrm{NHC})$ complexes, coupled with self-aldol condensation of the HTID product 2, discussed above, illustrates that C6 aldehydes chemistry can be accessed if $\mathbf{2}$ is allowed, or encouraged to further react after its formation. That can be achieved for example by running the HTID under pressure: 3 , a valuable chemical, commercially important because of its industrial applications, including in the food, pharmaceutical, cosmetic, and plasticizer fields, ${ }^{44,45,46}$ would be yielded via self-aldol-condensation of $\mathbf{2}$, after dehydration. Current work by the authors is focused on the selective production of the valuable C6 aldehyde 3 by running the HTID of 1,3-PDO under pressure. ${ }^{40}$

\section{Conclusions.}

43 H. Iqbal, F. Lorenzini, A.C. Marr et al. (2016) unpublished results.

44 T. Aida, T. Nagasawa, Y. Yamazaki, WO Pat. 065851, 2008.

45 S. Tanaka, K. Fukuda, T. Asada, WO Pat. 029033, 2004.

46 A.D. Godwin, R.H. Schlosberg, F. Hershkowitz, M.G. Matturro, G. Kiss, K.C. Nadler, P.L. Buess, R.C. Miller, P.W. Allen, H.W. Deckman, R. Caers, E.J. Mozeleski, R.P. Reynolds, (2001) U.S. Patent No. 6,307,093. Washington, DC: U.S. Patent and Trademark Office. 
We have shown that the fluorinated $\mathrm{Cp}^{*} \mathrm{IrCl}_{2}(\mathrm{NHC})$ complex 1-3F is a highly recyclable catalyst precursor for the efficient, selective production of 2 via HTID of 1,3-PDO in ionic liquids, under air. In comparison the related complex $\mathbf{1 - 2} \mathbf{C H}_{\mathbf{3}}$ has very poor catalytic activity. The use of 1-3F in ionic liquid enables HTID to proceed under controlled, reduced pressure: that facilitates product isolation and allows high selectivity, with minimal waste. In addition, HTID of 1,3-PDO to 2 in ionic liquids is successful also when a significant volume of water is involved in the reaction. A crucial role played in HTID by the ortho-grouping of the carbene ligand benzyl arm of $\mathrm{Cp}^{*} \mathrm{IrCl}_{2}(\mathrm{NHC})$ complexes is suggested by the inhibition of the catalytic activity observed when removing any $\mathrm{H}$ and $\mathrm{F}$ atoms bound to the ortho- $\mathrm{C}$ atoms. The successful synthesis and isolation of a value-added chemical from the ionic liquid solutions of 1,3-PDO, representing the ionic liquid solutions extracting the diol from the aqueous glycerol fermentation broths, ${ }^{47}$ demonstrates the valorisation of waste to chemicals. Combining bio-catalytic treatment of waste glycerol with $\mathrm{Cp}^{*} \operatorname{IrX}_{2}(\mathrm{NHC})$ - catalysed HTID of 1,3-PDO in ionic liquids has the ultimate potential to allow production of valuable chemicals, which can be simply isolated, directly from a renewable sources.

47 X.-h. Liu, M. Rebroš, I. Dolejš, A.C. Marr, ACS Sustainable Chem. Eng. DOI: 10.1021/acssuschemeng.7b01934. 


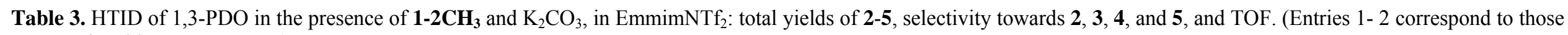
in tables S8, S18, S28.)

\begin{tabular}{|c|c|c|c|c|c|c|c|c|c|c|c|c|}
\hline Entry & Solvent & Catalyst & [1,3-PDO]:[Ir] & Base & [Base]:[1,3-PDO] & $\mathrm{T}$ & $\%$ Yield $(2-5)^{\mathrm{a}}$ & 2 & 3 & 4 & 5 & $\operatorname{TOF}^{\mathrm{b}}\left[\mathrm{s}^{-1}\right]\left(\times 10^{3}\right)$ \\
\hline 1 & EmmimNTf $_{2}$ & $1-2 \mathrm{CH}_{3}$ & 49.1 & $\mathrm{~K}_{2} \mathrm{CO}_{3}$ & 0.0308 & 150 & $\leq 3$ & 1.6 & 0.6 & 0.1 & 97.8 & 0.07 \\
\hline 2 & EmmimNTf $_{2}$ & $1-2 \mathrm{CH}_{3}$ & 99.1 & $\mathrm{~K}_{2} \mathrm{CO}_{3}$ & 0.0300 & 120 & $<0.5$ & l & / & / & I & I \\
\hline
\end{tabular}

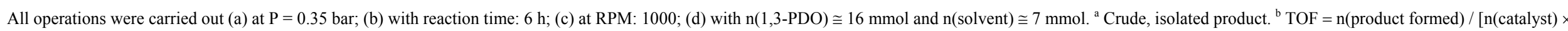
time]. 


\section{Acknowledgements}

This work was supported by GRAIL (Grant agreement no: 613667), project co-financed by the European Commission under the $7^{\text {th }}$ Framework Programme. The assistance provided by Queen's University Ionic Liquid Laboratories (QUILL), and the analytical chemistry service (ASEP) and glassblowing service at Queen's University Belfast, is acknowledged. 